\title{
Flora da Bahia: Pontederiaceae
}

\author{
Danilo José Lima de Sousa ${ }^{*}$ \& Ana Maria Giulietti1,2,a \\ ${ }^{1}$ Programa de Pós-graduação em Botânica, Departamento de Ciências Biológicas, Universidade Estadual de Feira \\ de Santana, Bahia, Brasil. \\ ${ }^{2}$ Royal Botanic Gardens, Kew, United Kingdom.
}

\begin{abstract}
Resumo - É apresentado o levantamento florístico de Pontederiaceae no estado da Bahia, Brasil. Foram reconhecidas seis espécies do gênero Eichhornia: E. azurea, E. crassipes, E. diversifolia, E. heterosperma, E. paniculata e E. paradoxa; sete de Heteranthera: H. multiflora, $H$. oblongifolia, H. peduncularis, H. reniformis, H. rotundifolia, H. seubertiana e H. zosterifolia; quatro de Pontederia: P. cordata, P. rotundifolia, $P$. sagittata e $P$. subovata; além de Hydrothrix gardneri. O tratamento inclui descrição e comentários para os táxons, chaves de identificação, ilustrações e mapas de distribuição das espécies na Bahia.
\end{abstract}

Palavras-chave adicionais: macrófitas aquáticas, Nordeste, taxonomia.

\begin{abstract}
Flora of Bahia: Pontederiaceae.) - The floristic survey of the Pontederiaceae from Bahia State, Brazil, is presented. Six species of the genus Eichhornia were recognized: E. azurea, E. crassipes, E. diversifolia, E. heterosperma, E. paniculata and E. paradoxa; seven of Heteranthera: H. multiflora, H. oblongifolia, H. peduncularis, H. reniformis, H. rotundifolia, H. seubertiana and H. zosterifolia; four of Pontederia: P. cordata, P. rotundifolia, P. sagittata and P. subovata; and Hydrothrix gardneri. The treatment includes descriptions and comments for taxa, a key for identification, illustrations and distribution maps of the species.
\end{abstract}

Additional key words: aquatic macrophytes, Northeast Brazil, taxonomy.

\section{Pontederiaceae}

Ervas dulciaquicolas, perenes ou anuais, emergentes, flutuantes fixas, flutuantes livres ou submersas, rizomatosas ou estoloníferas. Raízes numerosas, não septadas. Folhas alternas, dísticas, espiraladas ou verticiladas, ao longo do caule ou basais, heteromórficas; pecíolo cilíndrico, ocasionalmente inflado; limbo acicular, linear a oval, ápice agudo a arredondado, base atenuada a sagitada, margem inteira, venação acródoma a campilódroma. Inflorescências determinadas, frequentemente cimeiras, às vezes tirsoides, cincinos, ou inflorescências compostas por unidades de cincinos, uni a multifloras; bráctea parcialmente fusionada ou não, triangular a oboval. Flores trímeras, bissexuadas, sésseis, raramente curto-pediceladas; perigônio zigomorfo, formado por 3 tépalas externas e 3 internas, unidas na base em um tubo, externamente sem tricomas ou com tricomas geralmente glandulares; lobos externos geralmente elípticos, 1 mediano posterior e 2 laterais; os internos geralmente ovais, 1 mediano anterior e 2 laterais, lobos laterais quando associados ao lobo anterior denominados de anteriores e quando associados ao lobo posterior denominados de posteriores; lilás, azul, amarelo ou branco, lobo mediano anterior geralmente com mácula basal ou mediana, face abaxial dos lobos

\footnotetext{
*Autor para correspondência: danilojls@yahoo.com.br; anagiulietti@hotmail.com

Editor responsável: Abel Augusto Conceição

Submetido: 5 mar. 2014; aceito: 23 jul. 2014

Publicação eletrônica: 30 dez. 2014; versão final: 20 jan. 2015
}

acompanhando o indumento do tubo; androceu com 1, 3 ou 6 estames, livres entre si, adnatos ao tubo do perigônio, anteras 2-tecas, basifixas a dorsais, rimosas; carpelos 3 , sincárpicos, ovário súpero, trilocular, multi ou uniovulado, placentação apical, axilar ou parietal, óvulos anátropos, estigma capitado ou lobado. Fruto cápsula loculicida ou aquênio, frequentemente acompanhado com o tubo do perigônio, formando um antocarpo desenvolvido (alado ou equinado) ou não (não alado, não equinado, se rasgando com $o$ desenvolvimento do fruto). Sementes númerosas ou 1 por fruto, testa glabra, lisa ou costada longitudinalmente, castanho-claras a escuras.

Pontederiaceae possui distribuição pantropical, porém está melhor representada nas Américas, onde ocorre mais de $70 \%$ das espécies da família. São reconhecidos cinco gêneros e aproximadamente 34 espécies: Heteranthera Ruiz \& Pav. (12 espécies), com distribuição nas Américas e porção Sul da África; Pontederia L. (6), com distribuição nas Américas e Austrália; Eichhornia Kunth (8), com distribuição nas Américas, Austrália, África e Ásia; Monochoria C.Presl (7), com distribuição nos continentes asiático, africano e australiano; e Hydrothrix Hook.f., monospecífico, endêmico do Nordeste brasileiro (Schulz 1942; Lowden 1973; Horn 1985; Crow 2003).

Nas análises filogenéticas com dados combinados de regiões plastidiais $(r b c \mathrm{~L}$ e $n d h \mathrm{~F})$ e nucleares (seis ESTs), Ness et al. (2011) confirmaram o monofiletismo de Monochoria, enquanto Eichhornia e Heteranthera despontaram como não monofiléticos. Os autores ainda questionaram o monofiletismo de 
Pontederia, devido ao posicionamento incerto de Eichhornia azurea, que, em alguns cladogramas, aparece agrupado com espécies de Pontederia.

Schwartz (1930) dividiu a família em três tribos: Pontederieae, Eichhornieae e Heteranthereae, onde estava incluído o gênero Monochoria. Entretanto, Cook (1998) trata esse gênero na tribo Eichhornieae, pela presença de seis estames e cápsulas com muitas sementes. A divisão da família em tribos é pouco usual, principalmente por se tratarem de grupos artificiais (Graham et al. 1998; Ness et al. 2011).

Nos sistemas de Hutchinson (1959), Takhtajan (1980) e Cronquist (1981), a família foi relacionada às Liliaceae, principalmente por características florais. Já Dahlgren \& Clifford (1982) propuseram a ordem Pontederiales, inserida na superordem Bromelianae, relacionada com as Haemodorales e Phyllidrales devido a algumas características "liliáceas". Em contrapartida, Thorne (1983) e Dahlgren et al. (1985) posicionaram Pontederiaceae relacionado-a com as Commelinaceae. De acordo com Graham et al. (2002), Saarela et al. (2008) e o APG III (2009), Pontederiaceae está inserida nas commelinídeas, formando um grupo monofilético aparentemente sustentado por uma sinapomorfia química: a presença de ácidos orgânicos nas paredes celulares, fluorescente em luz UV. A família é uma das integrantes da ordem Commelinales e está relacionada às Philydraceae e Haemodoraceae, sendo esta última tratada por Simpson \& Burton (2006) como grupo irmão de Pontederiaceae, pela presença de grãos de pólen com paredes não tectado-columeladas.

Para o Brasil, Amaral (2014) cita 19 espécies e duas variedades, distribuídas por todas as Regiões do país, e refere 13 espécies para a Bahia. Neste trabalho, através da análise de materiais de herbários e de cultivo, apresentamos números atualizados para as espécies da família no estado, além de informações sobre a morfologia e horário de antese das flores (Apêndice). Foram reconhecidos para a Bahia, quatro gêneros e 18 espécies: Eichhornia (6 espécies), Heteranthera (7), Hydrothrix (H. gardneri) e Pontederia (4).

\section{Chave para os gêneros}

1. Flores com 6 estames.

2. Ovário com 3 lóculos férteis, multiovulados; fruto cápsula loculicida; sementes costadas.

1. Eichhornia

2'. Ovário com apenas 1 lóculo fértil, uniovulado; fruto aquênio; sementes lisas

4. Pontederia

1'. Flores com 1 ou 3 estames.

3. Plantas com filotaxia alterna dística ou espiralada; limbo linear a arredondado; androceu com 3 estames ou 1 estame e 2 estaminódios ....

2. Heteranthera

3'. Plantas com filotaxia verticilada; limbo acicular; androceu com 1 estame, sem estaminódios
1. Eichhornia Kunth, Enum. P1. 4: 129. 1843.

Ervas emergentes, flutuantes fixas ou flutuantes livres. Folhas alternas, dísticas ou espiraladas, basais ou ao longo do caule, pecioladas; pecíolo inflado ou não, cilíndrico; limbo linear ou arredondado; ápice agudo a arredondado; base atenuada a cordada. Inflorescências em cimeiras, às vezes tirsoides, cincinos ou panículas, tri a multiflora; brácteas obovais a triangulares, frequentemente cimbiformes, parcialmente fechadas ou abertas; raque glabra ou pubescente. Flores sésseis, lilás; tubo do perigônio com face externa glabra ou pubescente; lobos externos com margem inteira, 1 posterior elíptico e 2 anteriores elípticos, lobos internos com margem inteira, erosa ou fimbriada, 1 anterior e 2 posteriores $(3+3)$, lilás, lobo mediano anterior geralmente com mácula, face abaxial dos lobos acompanhando o indumento do tubo; estames 6, filetes cilíndricos, brancos a lilás, glabros, pubescentes ou pilosos, anteras homomorfas, elípticas a sagitadas, basifixas, azuladas ou amarelas; ovário lilás, verde ou vináceo, glabro, trilocular, todos os lóculos férteis, multiovulados, estilete vináceo a branco, glabro, pubescente ou viloso, estigma capitado ou lobado, branco a lilás. Cápsulas castanhas, vináceas a esverdeadas; antocarpo enegrecido, torcido no ápice ou não, liso, não alado. Sementes elipsoides, oblongas ou botuliformes, costadas.

De acordo com Graham et al. (2002) e Ness et al. (2011), Eichhornia forma um gênero polifilético, distinguido pelas flores grandes, geralmente maiores que $3 \mathrm{~cm}$ de comprimento, lilás, em inflorescências laxas; androceu com seis estames, anteras homomorfas e ovário trilocular, com lóculos multiovulados. É um gênero cosmopolita, com seis espécies, todas ocorrentes no Brasil, se distribuindo em praticamente todo o território (Amaral 2014). Na Bahia, apresentam uma ampla distribuição, ocorrendo em todos os domínios fitogeográficos.

\section{Chave para as espécies}

1. Plantas emergentes ou flutuantes livres, eretas, folhas basais; estilete piloso, pubescente ou viloso.

2. Pecíolo frequentemente inflado; bráctea da inflorescência com ápice foliáceo; estilete pubescente na porção apical .... 1.2. E. crassipes

2'. Pecíolo nunca inflado; bráctea da inflorescência, quando presente, com ápice agudo; estilete piloso ou viloso na porção apical.

3. Limbo foliar largo-oval; inflorescências em panículas, pedunculadas, bráctea triangular; estilete piloso ................. 1.5. E. paniculata

3'. Limbo foliar elíptico a lanceolado; inflorescências em cincinos, não pedunculadas, bráctea ausente; estilete viloso 1.6. E. paradoxa

1'. Plantas flutuantes fixas, decumbentes, folhas ao longo do caule; estilete glabro.

4. Folhas flutuantes; cimeiras (2)3-floras 
4'. Folhas emersas; cimeiras 7-37-floras.

5. Raque da inflorescência pubescente; flor com lobo mediano anterior com mácula circular amarela; sementes homomorfas no mesmo fruto; filetes pubérulos 1.1. E. azurea

5'. Raque da inflorescência glabra; flor com lobo mediano anterior sem mácula; sementes heteromorfas no mesmo fruto; filetes glabros

1.4. E. heterosperma

1.1. Eichhornia azurea (Sw.) Kunth., Enum. Pl. 4: 129. 1843.

Figuras $1 \mathrm{~A}-\mathrm{G}, 2$ e $6 \mathrm{~A}$.

Erva flutuante, fixa, decumbente, $16-45 \mathrm{~cm}$ alt. Folhas submersas alternas, espiraladas, ao longo do caule, sesséis; limbo linear, 9-11 $\times 0,4-0,5 \mathrm{~cm}$, pubérulo, ápice obtuso, base truncada; lígula membranácea, $0,4-0,7 \mathrm{~cm}$ compr., hialina a esverdeada, ápice truncado a bilobado. Folhas emersas alternas, dísticas, ao longo do caule; pecíolo nunca inflado, 9-24 × 0,3-0,6 cm, verde a castanho, glabro; limbo largo-elíptico a oboval, raramente arredondado, 7-17,5 × 4,4-12 cm, glabro, ápice obtuso a arredondado, base atenuada; lígula membranácea a foliácea, 2,5-18 cm compr., esverdeada a castanha, ápice truncado. Cimeiras 10-37-floras; pedúnculo 2,5-4 cm compr.; bráctea oboval, ca. 5,3 cm compr., ápice retuso, mucronado; raque $9-15 \mathrm{~cm}$ compr., pubescente. Flores com tubo do perigônio 17-29 mm compr., esverdeado com ápice azulado a lilás, face externa pubérula; lobos externos com margem inteira, 18-28 mm compr., 1 posterior e 2 anteriores elípticos, lobos internos com margem erosa a fimbriada, 20-29 mm compr., 1 anterior oboval a largo-elíptico, lilás com base azul com mácula mediana amarela, e 2 posteriores obovais, lilás; estames 6, 3 maiores, pubérulos na porção apical. Cápsulas e sementes não vistas.

Ocorre nas Américas, desde os Estados Unidos até a Argentina (Schulz 1942; Castellano 1958). Para o Brasil, Amaral (2014) cita a espécie para as cinco Regiões, mas com registros apenas para o Ceará e o Maranhão no Nordeste. C5, D1, D4, D7, E6, F6: nas margens de rios como o São Francisco e o Rio Grande, ou em lagoas temporárias e açudes.

Material selecionado - Andaraí, Marimbus, 1245'53”S, 41 ${ }^{\circ} 18^{\prime} 47^{\prime \prime}$ W, 26 fev. 2005, E. Melo et al. 3762 (HUEFS); Barra, Pedrinhas, Rio Grande, 16 fev. 2013, D.J.L. Sousa et al. 242

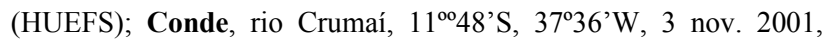
D.L. Santana et al. 652 (CEPEC); Formosa do Rio Preto, Arroz de

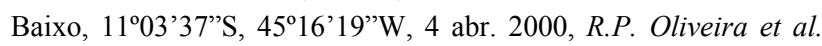
511 (CEPEC, HUEFS); Irecê, $10^{\circ} 40^{\prime} \mathrm{S}, 42^{\circ} 41^{\prime} \mathrm{W}, 19$ jun. 2000, M.L. Guedes et al. 7361 (ALCB, CEPEC); Jacobina, Lagoa

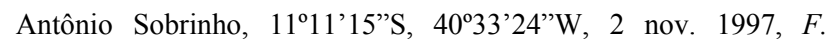
França et al. 2462 (HUEFS); Lençóis, Remanso, 12³9'S, 4119'W, 29 jan. 1997, S. Atkins et al. PCD 4651 (HUEFS, SPF); Livramento do Brumado, encontro dos rios Paulo e Brumado, 26 maio 1991, A.J. Ribeiro 300 (ALCB); Utinga, povoado Taparica,

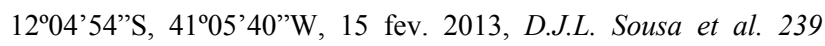

(HUEFS); Xique-Xique, Dunas do Rio São Francisco, 1047'16”S, 4246'22”'W, 23 jun. 1996, A.M. Giulietti et al. PCD 2986 (CEPEC, HRB, HUEFS, SPF).

Eichhornia azurea é geralmente confundida com $E$. heterosperma, pela forma de crescimento e pelo formato das folhas. Entretanto, E. azurea apresenta a raque da inflorescência e filetes pubérulos com tricomas glandulares que, em plantas herborizadas, apresentam uma célula basal alaranjada ou enegrecida (enquanto que em E. heterosperma, a raque é glabra). Para a Bahia, são encontradas plantas com flores brevistilas e medistilas. As flores apresentam o início da antese em torno de 6:00 horas da manhã e permanecem abertas até cerca das 17:00 horas.

\subsection{Eichhornia crassipes (Mart.) Solms., Monogr.}

Phan. 4: 527. 1883.

Figuras $1 \mathrm{H}-\mathrm{M}, 2$ e $6 \mathrm{~B}$.

Erva flutuante livre, raramente emergente, ereta, $10-60 \mathrm{~cm}$ alt. Folhas submersas não vistas. Folhas emersas alternas, espiraladas, basais; pecíolo inflado quando flutuante livre, 5-50,5 × 0,9-7 cm, verde, glabro; limbo orbicular a oval, 5-12,5 × 4,9-11 cm, verde, glabro, ápice obtuso a arredondado, raramente retuso, base atenuada a truncada, raramente levemente cordada; lígula membranácea a foliácea, 2-6 cm compr., esverdeada a vinácea, ápice foliáceo. Cimeiras 5-12-floras; pedúnculo 1-2 cm compr.; bráctea oboval, ca. 3,5 cm compr., ápice mucronado; raque $5-8 \mathrm{~cm}$ compr., pubérula. Flores com tubo do perigônio 10-15 $\mathrm{mm}$ compr., esverdeado, face externa pubérula; lobos externos com margem inteira, 20-28 mm compr., 1 posterior e 2 anteriores elípticos a obovais, lobos internos com margem inteira, 23-30 mm compr., 1 anterior largo-elíptico, lilás com mácula amarela circundada por azul, e 2 posteriores obovais, lilás; estames 6, 3 maiores pubérulos na aporção apical. Cápsulas e sementes não vistas.

Dentre as Pontederiaceae, é a espécie de distribuição mais ampla, com registros para os continentes asiático, africano e americano (Schulz 1942; Castellanos 1958; Kuo-fang \& Horn 2000). Para o Brasil, Amaral (2014) cita a espécie para todas as Regiões, e no Nordeste, registra a ocorrência para a Bahia, Maranhão e Pernambuco. É a espécie com maior distribuição na Bahia. B7, C8, D2, D4, D6, D7, D10, E8, E9, G4, G8, H9, I8: em rios grandes e pequenos riachos, além de outros corpos d'água, como açudes e lagoas temporárias; facilmente encontrada em águas de perímetros urbanos, que pode estar relacionado a ambientes ricos em matéria orgânica.

Material selecionado - Alagoinhas, Fonte dos Frades, 7 dez. 1992, E. Mendes s.n (ALCB 27754); Anguera, $12^{\circ} 11^{\prime}$ 'S, $39^{\circ} 09^{\prime} \mathrm{W}, 3$ nov. 1996, E. Melo et al. 1815 (HST, HUEFS, SPF); Barra do Rocha, Assentamento Coroa Verde, 14¹0'47'S, 39³6'47'W, 16 ago. 2001, M.L. Guedes et al. 9405 (ALCB); Cabaceiras do Paraguaçu, rio Paraguaçu, 12³3'02,9'S, 3909'00,4”'W, 9 nov. 2012, G.A. Pece \& L.Y.S. Aona 1 (HURB); Cachoeira, Estação da 


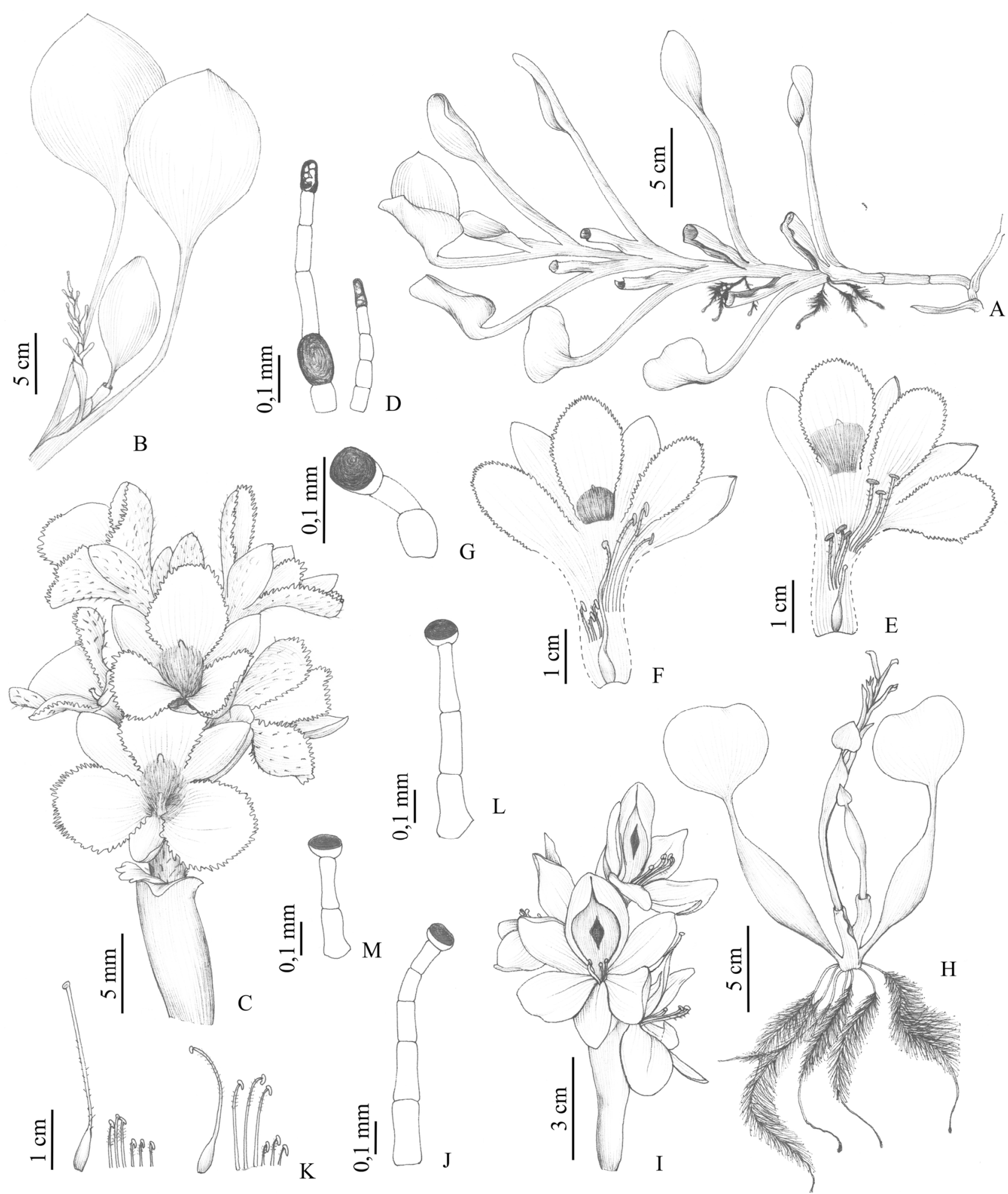

Figura 1. A-G. Eichhornia azurea: A- hábito; B- porção apical com detalhe do ramo florífero; C- inflorescência; D- tricomas da face externa das flores e da raque; E- flor brevistila; F- flor medistila; G- tricoma dos filetes. H-M. E. crassipes: H- hábito; I- inflorescência; J- tricoma da face externa do tubo do perigônio e raque; K- androceu e gineceu de uma flor medistila e longistila; L- tricoma dos filetes; M- tricoma dos estiletes. (A-G- Sousa 239; H-M- Sousa 303)

Embasa, 12³1'59'S, 3904'59'W, maio 1980, Grupo Pedra do Cavalo 104 (ALCB, CEPEC, EAC, HRB, N); Camaçari, Praia do Forte, 19 dez. 1993, M.L. Guedes et al. 3154 (CEPEC); Canavieiras, Betanha, 6 ago. 1964, C.M. Magalhães 179 (CEPEC); Carinhanha, 14'19'39"S, 4346'40"W, 26 nov. 2007, M.L. Guedes et al. 13988 (HUEFS); Conde, Sítio do Conde, $11^{\circ} 48^{\prime}$ S 37³6'W, 4 nov. 2011, D.L. Santana et al. 673 (ALCB, MBM); Cruz das Almas, fazenda Campo Limpo, 1240'33,8”'S, 3903'44,5"W, 6 out. 2009, M.P. Sousa \& L.Y.S. Aona 23 (HURB); Feira de Santana, Estrada do Feijão, 12¹1'35"S, 3909'03”'W, 23 fev. 2005, K.R. Leite et al. 481 (HUEFS); Formosa do Rio Preto, Arroz de Baixo, $11^{\circ} 34^{\prime} 10^{\prime \prime S}, 45^{\circ} 16^{\prime} 19^{\prime \prime} \mathrm{W}, 4$ abr. 2000, R.P. Oliveira et al. 511 
(EAC); Ibicaraí, Salomeia-rio Cachoeira, 1452'49'S, 39³7'23”'W, 24 set. 2002, E. Rocha 988 (HUESC); Ilhéus, rio Cachoeira, 1448'54"S, 3908'96”'W, 13 abr. 2003, E.A. Rocha 1092 (UFP); Ipirá, 12²2'S $38^{\circ} 41^{\prime}$ 'W, jul. 2001, A.M. Giulietti et al. 2581 (EAC, HUEFS); Irecê, Estrada do Feijão, $11^{\circ} 18^{\prime} \mathrm{S}, 41^{\circ} 51^{\prime} \mathrm{W}, 29$ abr. 2006, M.L. Guedes et al. 12420 (ALCB); Itabuna, rio Cachoeira, 23 set. 1965, R.P. Belém 1789 (CEPEC); Itapé, rio Cachoeira, 12 jun. 1996, C.S. Florêncio 46 (CEPEC, HUEFS); Itiúba, Lagoa da Eugenia, 1040'S, 3943'W, 20 fev. 1974, R.M. Harley 16261 (IPA, K, N); Juazeiro, rio São Francisco, 09²5'24,6”S, 40³0'05,4”W, 21 set. 2011, C.R.S. Oliveira et al. 12 (HVASF); Lauro de Freitas, Areia Branca, 2 jul. 2005, V.R. Matos et al. 09 (HUEFS); Mata de São João, rio Açu, $12^{\circ} 31^{\prime}$ S, $38^{\circ} 17^{\prime} \mathrm{W}, 23$ mar. 2000, D.L. Santana

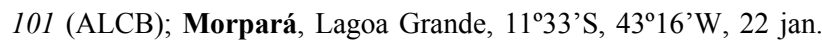
2001, M.L. Guedes et al. 7822 (CEPEC, HRB, HUEFS, UEC); Pilão Arcado, lagoa Jatobá, 1000'11'S, 42³0'16”'W, 12 nov. 2009, A.P. Prata 1999 (ASE); Muritiba, Pedra do Cavalo, 12³5'84,2"S, 3900'24,2”'W, 24 jul. 2012, L.Y.S. Aona et al. 1488 (HURB); Porto Seguro, Rio do Peixe, 21 nov. 1978, A. Euponino 377 (CEPEC, SPF); Remanso, vila Cardoso, 19 fev. 2013, D.J.L. Sousa et al. 303 (HUEFS); Salvador, Instituto de Biologia, 10 out. 1975, Equipe de Ecologia s.n. (ALCB 701); Ubaitaba, Rio de

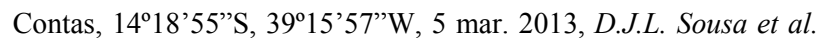
307 (HUEFS); Várzea da Roça, rio Paraguaçu, $11^{\circ} 36^{\text {'S }}, 40^{\circ} 08^{\prime} \mathrm{W}$, 26 dez. 2008, M.S. Silva 10 (ALCB).

Eichhornia crassipes recebeu esse nome devido aos pecíolos inflados (do latim crassus, significando grosso), sendo esta uma de suas principais características. Entretanto, em indivíduos que se fixam no substrato, os pecíolos são compridos e de menor diâmetro. Neste caso, a caracterização da espécie pode ser feita através das folhas basais com limbos reniformes a largo-elípticos e pelas brácteas com ápice foliáceo. Para a Bahia, foram encontradas apenas plantas com flores medistilas e longistilas, e que apresentam a antese iniciando em torno das 6:00 horas da manhã e mantêmse abertas até cerca de 17:00 horas.

\subsection{Eichhornia diversifolia (Vahl) Urban, Symb.} Antill. 4: 147. 1903.

Figuras 2, 3A-I e 6C-D.

Erva flutuante fixa, $20-40 \mathrm{~cm}$ alt. Folhas submersas alternas, espiraladas, ao longo do caule, sésseis; limbo linear, $1-4 \times 0,2-0,6 \mathrm{~cm}$, verde, glabro, ápice agudo a obtuso, base truncada; lígula membranácea, ca. $2 \mathrm{~mm}$ compr., esverdeada, ápice truncado. Folhas flutuantes alternas, dísticas, ao longo do caule; pecíolo nunca inflado, 3,5-6,5 ×0,1-0,3 cm, vináceo, glabro; limbo arredondado a oval, 0,6-2,9 $\times$ 0,5-2,5 cm, glabro, ápice obtuso a arredondado, base cordada, lobos $0,1-0,5 \mathrm{~cm}$ compr., não imbricados; lígula, membranácea a foliácea, $1,5-4 \mathrm{~cm}$ compr., hialina a vinácea, ápice truncado. Cimeiras (2)3-floras; pedúnculo $0,7-1,2 \mathrm{~cm}$ compr.; bráctea estreito-oboval, cimbiforme, ca. 1,5 cm compr., ápice obtuso, levemente retuso, mucronado; raque 1,6-2,6 cm compr., pubérula. Flores com tubo do perigônio ca. $12 \mathrm{~mm}$ compr., vináceo, face externa pubérula; lobos externos com margem inteira, 9-13 $\mathrm{mm}$ compr., 1 posterior e 2

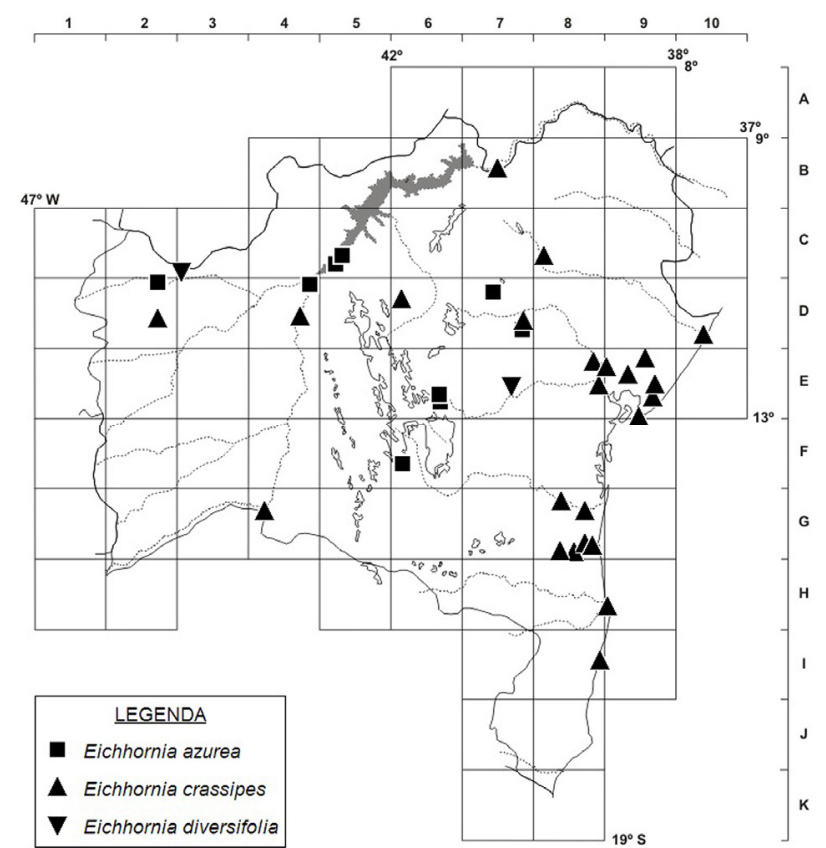

Figura 2. Distribuição de Eichhornia azurea, E. crassipes e E. diversifolia no estado da Bahia.

anteriores largo-elípticos, lobos internos com margem inteira, 11-16 mm compr., 1 anterior oboval, lilás com mácula amarela mediana, e 2 posteriores obovais, lilás; estames 6, em grupos de 2, glabros. Cápsulas ca. 15 mm compr., vináceas; antocarpo castanho, não torcido no ápice. Sementes homomorfas, elipsoides, 0,5-1 mm compr., castanho-claras.

Apresenta distribuição nas Américas, desde os Estados Unidos, passando pela América Central (Nicarágua), até a América do Sul, onde possui maior distribuição (Castellanos 1958; Crow 2003). Para o Brasil, é citada por Amaral (2014) para as Regiões Sudeste, Centro-Oeste, Norte e Nordeste, onde é referenciada para o Ceará, Maranhão, Paraíba e Pernambuco. C3, E7: apenas em áreas alagadas na região oeste e no rio Paraguaçu.

Material selecionado - Formosa do Rio Preto, Várzea do Anil, 10 ${ }^{\circ} 54^{\prime}$ 'S, 44 $56^{\circ}$ 'W, 23 fev. 2005, M.L. Guedes \& A.B. Xavier 11610 (ALCB); Itaberaba, rio Paraguaçu, 4 jun. 1995, F. França et al. 1214 (HUEFS).

Eichhornia diversifolia é de fácil reconhecimento pelas suas folhas flutuantes, pecioladas e com limbo cordiforme. Apresenta ainda inflorescências geralmente com três flores, apesar de alguns espécimes apresentarem apenas duas flores. Gomes (2000) afirma que amostras estéreis podem ser confundidas com Heteranthera reniformis. Porém, enquanto $E$. diversifolia apresenta folhas lineares e sésseis, persistente em todos os ramos submersos e as folhas pecioladas possuem a face abaxial, pecíolos e lígulas frequentemente vináceos, em H. reniformis as folhas lineares são efêmeras e encontradas apenas na fase jovem da planta, as folhas são concolores, com ambas as faces verdes, apresentando os pecíolos verdes. A espécie possui flores homostílicas que entram em antese cerca de 6:00 
horas da manhã e permanecem abertas até cerca das 12:00 horas.

1.4. Eichhornia heterosperma Alexander, Lloydia 2: 170. 1939.

Figuras 3J-O, 4 e 6E-F.

Erva emergente, decumbente, 9-14 cm alt. Folhas submersas alternas, espiraladas, ao longo do caule, sésseis; limbo linear, $12-14 \times 0,3-0,5 \mathrm{~cm}$, glabro, ápice obtuso, base truncada; lígula membranácea, 0,4$0,7 \mathrm{~cm}$ compr., hialina a esverdeada, ápice truncado a bilobado. Folhas emersas alternas, dísticas, ao longo do caule; pecíolo nunca inflado, 6,5-9,5 × 2-4 cm, verde a vináceo, glabro a pubérulo; limbo oboval, raramente arredondado, 5-8 × 2,5-5,5 cm, glabro, ápice obtuso a arredondado, base atenuada; lígula membranácea a foliácea, 1,5-3 cm compr., vinácea, ápice truncado. Cimeiras 7-10-floras; pedúnculo 0,7$1,8 \mathrm{~cm}$ compr.; bráctea oboval, cimbiforme, ca. $5,3 \mathrm{~cm}$ compr., ápice obtuso levemente retuso, não mucronado; raque 3-3,8 cm compr., glabra. Flores com tubo do perigônio 11-17 mm compr., esverdeado, face externa pubérula; lobos externos com margem inteira, 9-13 $\mathrm{mm}$ compr., 1 posterior e 2 anteriores elípticos, lobos internos com margem erosa, 11-14 mm compr., 1 anterior largo-elíptico a oboval, lilás com base azulada, mácula ausente, e 2 posteriores largoelípticos, lilás; estames 6, glabros. Cápsulas 10-15 mm compr., castanhas; antocarpo enegrecido, torcido no ápice. Sementes heteromorfas, elipsoides ou oblongas, 1,5-2 mm compr., castanhos.

Ocorre nas Américas, desde o México passando pela América Central até a Bolívia e o Brasil (Novelo \& Ramos 1998; Crow 2003; Amaral 2014). No Brasil, é citada por Amaral (2014) para a Região Nordeste, nos estados do Ceará, Pernambuco, Piauí e Bahia. D2, E9, E10, H9: em lagoas e rios litorâneos e alagados na região oeste do estado.

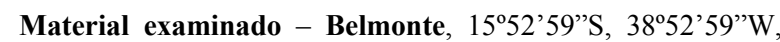
26 mar. 1974, R.M. Harley et al. 17467 (CEPEC, IPA, K); Candeias, BR-324/fazenda lagoa azul, 12³8'41's, 38'28'41'W, 9 set. 2004, K.R.B. Leite \& E.L. Neves 438 (HUEFS); Conde, Fazenda do Bu/Mata do Bebedouro, 12 02'24'S, 37\%42'38'W, 20 jun. 1996, T. Ribeiro et al. 27 (HRB, HUEFS); Formosa do Rio Preto, arredores da cidade, $11^{\circ} 03^{\prime} 08^{\prime \prime} \mathrm{S}, 45^{\circ} 11^{\prime} 27^{\prime \prime} \mathrm{W}, 29$ abr. 2000 , F. França et al. 3249 (ALCB, CEPEC, HUEFS, HRB); Itanagra, fazenda Buri, $12^{\circ} 15^{\prime} 47^{\prime \prime}$, 38 $38^{\circ} 02^{\prime} 30^{\prime \prime} \mathrm{W}, 8$ dez. 1982, H.P. Bautista et al. 662 (CEPEC, HRB, HUEFS, INPA); Mairi, São Bento das Lajes, P. Luetzelburg 252 (K); Pilão Arcado, sítio Poção, 1007'S, 42³3'W, 10 nov. 2009, A.P. Prata 2042 (ASE).

Material adicional examinado - BRASIL. CEARÁ: Iguatu, 18 jul. 2010, L.R.O. Normando et al. 458 (EAC); 18 jul. 2010, L.R.O. Normando et al. 426 (EAC); lagoa das lajes, 18 jul. 2010, L.R.O. Normando et al. 454 (EAC).

Eichhornia heterosperma é similar morfologicamente a E. azurea, porém as plantas de E. heterosperma são mais delicadas e suas inflorescências são menores e com menor número de flores. Crow (2003) cita como diferenças entre as duas espécies as tépalas internas, com lobos de margem inteira em E. heterosperma e margem erosa ou fimbriada em $E$. azurea. O exame dos espécimes da Bahia mostrou que as tépalas internas das flores de $E$. heterosperma também apresentam margem erosa. Mesmo assim, as duas espécies são distintas por caracteres da inflorescência e das flores. Em $E$. heterosperma, a raque da inflorescência é glabra, o lobo da tépala mediana anterior não apresenta mácula amarela, os filetes são glabros, enquanto que $E$. azurea a raque da inflorescência é pubescente, o lobo da tépala mediana anterior apresenta uma mácula amarela, e os filetes são pubérulos. Eichhornia heterosperma vinha sendo considerada uma das poucas espécies homostílicas do gênero (Graham \& Barret 1995), porém com a análise dos espécimes da Bahia e de espécimes adicionais do Ceará foram encontradas flores medistilas e longistilas. As flores apresentam antese iniciando em torno das 6:00 horas da manhã, permanecendo abertas até cerca das 12:00 horas.

\subsection{Eichhornia paniculata (Spreng.) Solms., Monogr.} Phan. 4: 530. 1883.

Figuras 4, 5A-K e 6G.

Erva emergente, ereta, 33-60 cm alt. Folhas submersas não vistas. Folhas emersas alternas, espiraladas, basais; pecíolo nunca inflado, 10-55 × 0,3$1 \mathrm{~cm}$, verde, glabro; limbo largo-oval a largolanceolado, 3,8-11,5 × 1,3-11 cm, glabro, ápice agudo raramente obtuso, base cordada, lobos $0,5-2,5 \mathrm{~cm}$ compr., frequentemente não imbricados; lígula membranácea, 4,5-7,5 cm compr., hialina a esverdeada, ápice truncado. Panículas 14-131-floras; pedúnculo 1-4 cm compr.; bráctea triangular, ca. $3 \mathrm{~cm}$ compr., ápice agudo, mucronado, múcron ca. $3 \mathrm{~mm}$ compr.; raque $7-$ $25 \mathrm{~cm}$ compr., verde, pubérula. Flores com tubo do perigônio ca. $10 \mathrm{~mm}$ compr., esverdeado com ápice azulado a lilás, face externa pubérula; lobos externos com margem inteira, ca. $14 \mathrm{~mm}$ compr., 1 posterior e 2 laterais anteriores elípticos, lobos internos com margem inteira, ca. $15 \mathrm{~mm}$ compr., 1 anterior largoelíptico a oboval, lilás com base branca a azulada, duas máculas amarelas, e 2 posteriores largo-elípticos a obovais, lilás; estames 6, 3 maiores pubescentes. Cápsulas ca. $10 \mathrm{~mm}$ compr., verdes; antocarpo enegrecido, torcido no ápice. Sementes homomorfas, arredondadas, 0,8-1,0 mm compr., castanhas.

Tem distribuição nas Américas, porém é melhor representada na América do Sul (Schulz 1942; Castellanos 1958; Novelo \& Ramos 1998; Crow 2003). Para o Brasil, Amaral (2014) cita a espécie apenas para a Região Nordeste, nos estados da Bahia, Ceará, Pernambuco e Sergipe. B7, B8, C7, C9, D7, D8, D9, D10, E7, E8, E9, F7: espécies com maior número de coletas na Bahia e apresenta populações se desenvolvendo em diversos tipos de hábitats dulciaquícolas na região semiárida do estado. 


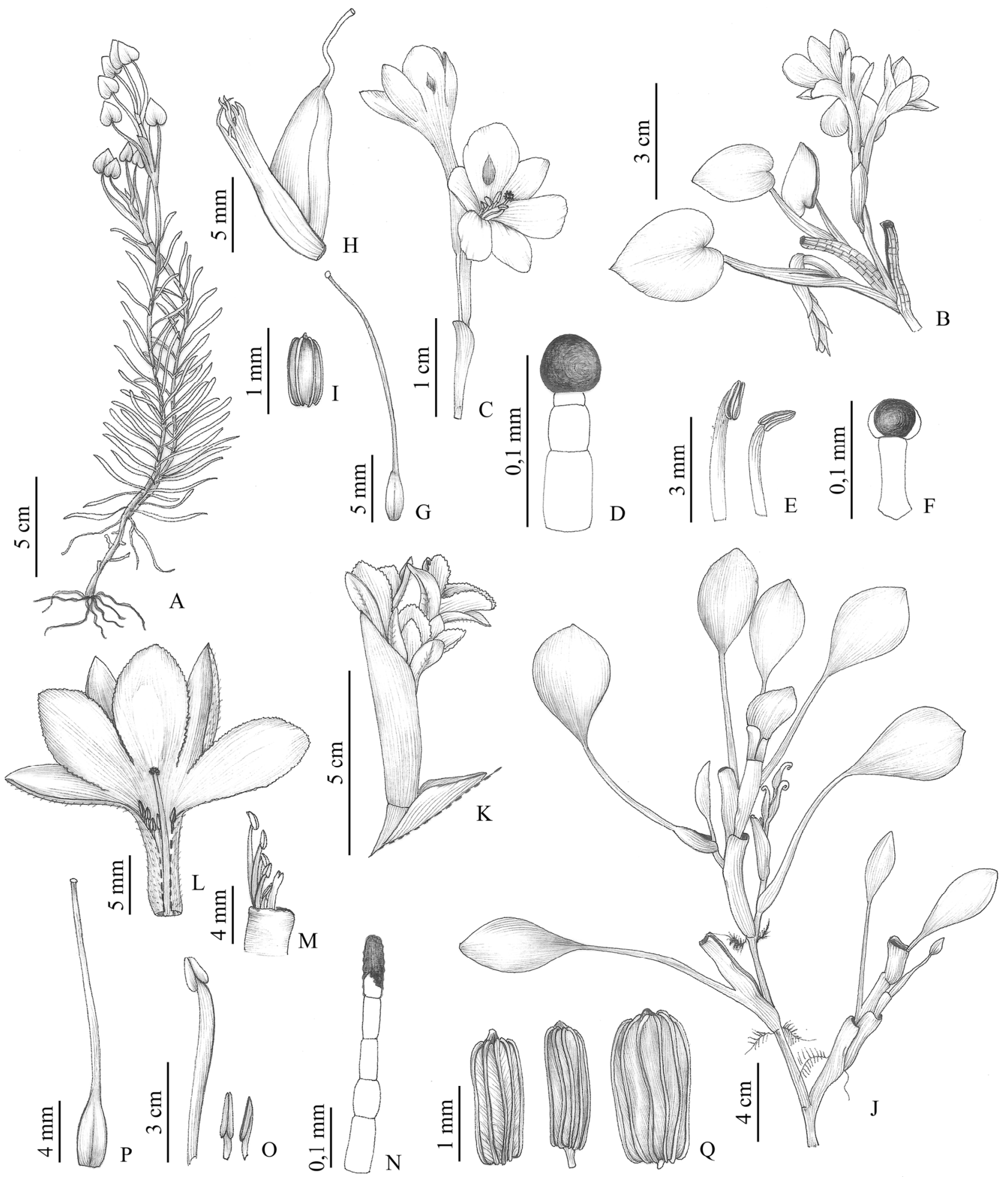

Figura 3. A-I. Eichhornia diversifolia: A- hábito; B- porção apical com detalhe do ramo florífero; C- inflorescência; D- tricoma da face externa do tubo do perigônio e raque; $\mathbf{E}$ - estames; $\mathbf{F}$ - tricoma dos filetes; G- gineceu; H- fruto com antocarpo fendido; I- Semente. J-Q. $E$. heterosperma: J- hábito; K- inflorescência; L- flor longistila com corte longitudinal; M- detalhe do ápice do tubo do perigônio sem os lobos de uma flor medistila; $\mathbf{N}$ - tricoma da face externa do tubo do perigônio; $\mathbf{O}$ - 3 estames; P- gineceu; Q- sementes heteromórficas, provenientes do mesmo fruto. (A- França 3247; B-I- Sousa 99; J- Leite 438; K-Q- Normando 458)

Material selecionado - Anguera, $12^{\circ} 11^{\prime} \mathrm{S} 39^{\circ} 09^{\prime} \mathrm{W}, 18$ ago. 1996, F. França et al. 1762 (HRB, HUEFS, K); Cabaceiras do Paraguaçu, lago Garora, 12³7’95,7’S, 3857'67,7’'W, 7 ago. 2012, L.Y.S. Aona et al. 1551 (HURB); Cachoeira, Roncador, 12³1'59”S, 3904'59”'W, maio 1980, Grupo Pedra do Cavalo 268
(CEPEC, EAC, HRB, HUEFS, NY); Campo Formoso, Sacaíba, $10^{\circ} 21^{\prime} \mathrm{S}, 40^{\circ} 18^{\prime} \mathrm{W}, 5$ set. 1981, L.M.C. Gonçalves 199 (CEPEC,

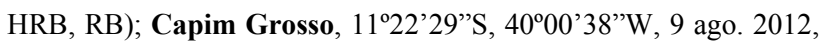
D.J.L. Sousa et al. 203 (HUEFS); Conde, estrada para Sítio do Conde, 18 ago. 1995, G. Hatschbach et al. 63131 (CEPEC, MBM); 
Cruz das Almas, Sapucaia, 28 out. 2008, L.Y.S. Aona 1202 (HURB); Entre Rios, 10 jan. 2011, M. B. B. Alves \& P. B. Alves 12 (ALCB); Feira de Santana, prox. de Tiquaruçu, $12^{\circ} 05^{\prime} \mathrm{S}, 38^{\circ} 54^{\prime} \mathrm{W}$, 20 ago. 1984, M. M. Santos et al. 171 (CEPEC, HRB, MBM); Iaçu, rio Paraguaçu, 10 jun. 1992, G. Hatschbach et al. 56967 (MBM, K); Ipirá, 12²1'S 39³7'W, 15 jul. 2001, E.C. Smidt 184 (HUEFS, SPF); Itaberaba, rio Paraguaçu, 4 jun. 1995, F. França et al. 1215 (HUEFS); Itatim, prox. ao Morro do Agenor, 12 $2^{\circ} 43^{\prime} \mathrm{S}, 39^{\circ} 42^{\prime} \mathrm{W}, 21$ abr. 1996, F. França et al. 1636 (HUEFS); Jacobina, Catuaba, 11¹0'22”S, 40³2'44”W, 4 jul. 1996, A.M. Giulietti et al. PCD3393 (ALCB, CEPEC, HUEFS); Jequié, BR-116, 1351'27'S, 4005'01'”, 16 fev. 1979, L.A.M. Silva et al. s.n (CEPEC 15714, NY 822686); Milagres, estrada para Iaçu, $12^{\circ} 52^{\prime} \mathrm{S}, 39^{\circ} 49^{\prime} \mathrm{W}, 31$ jan. 2000, A.M. Giulietti \& R.M. Harley 1971 (HUEFS); Remanso, Vila Cardoso, 19 fev. 2013, D.J.L. Sousa et al. 302 (HUEFS); Riachão do Jacuípe, fazenda São Pedro, 11²2'S, 3949'W, 10 jul. 1985, L.R. Noblick et al. 4059 (CEPEC, HUEFS); Salvador, 0803'52"'S, 3458'21'W, 3 dez. 2007, E.P. Queiroz 2562 (RB); Santa Brígida, 094'10"S, 3807'40”'W, 24 maio 1984, L.C. Oliveira-Filho 178 (ALCB, CEPEC, FLOR, HRB, IPA, MAC, MBM); Santana, $12^{\circ} 04^{\prime}$ S, $38^{\circ} 54^{\prime}$ W, 20 ago. 1984, M.M. Santos et al. 171 (CEPEC, MBM, RB); Santo Estevão, BR-116, 12³0'S, 39²2'W, 27 maio 1987, L.P. Queiroz et al. 1517 (CEPEC, HUEFS, HRB, MAC); São Félix, rio Paraguaçu, 3 jul. 2011, $F$. Esteves s.n (HUEFS 179037, HST 18799); São Sebastião do Passé, BR-324, 12³0'45"S, 38²9'43”W, 16 jul. 1983, J. L. Hage et al. 1717 (CEPEC); Tucano, Bizamum, 1053'37'S, 3858'21”W, 5 jun. 2004, D. Cardoso 75 (HUEFS); Uauá, Barrinha para Pilar, 0951'49"S, 4005'42”'W, 29 mar. 2000, E. Saar et al. 5 (ALCB, CEPEC, HUEFS): Sem localidade precisa, Sellow 164 (B); C.F.P. Martius s.n (M 18947).

Eichhornia paniculata é distinta das outras espécies do gênero pelas folhas basais cordiformes e pelas inflorescências paniculadas, com numerosas flores. Na Bahia, são encontradas plantas floridas principalmente após as chuvas de verão, sendo bem destacadas nas margens das lagoas, pelo porte alto e belas inflorescências roxas. Foram analisadas plantas com flores brevistilas, medistilas e longistilas. As flores iniciam a antese em torno das 7:00 horas da manhã e permanecem abertas até cerca das 15:00 horas.

1.6. Eichhornia paradoxa (Mart.) Solms., Monogr. Phan. 4: 531. 1883.

Figuras 4, 5J-O e 6H-I.

Erva emergente, ereta, $15-70 \mathrm{~cm}$ alt. Folhas submersas não vistas. Folhas emersas alternas, espiraladas, basais; pecíolo nunca inflado, 10-60 $\times$ 0,3-1 cm, verde, com estrias vináceas, glabro; limbo linear a estreito-lanceolado, ca. 9,6 ×0,4 cm, glabro, ápice agudo a obtuso, base atenuada; lígula membranácea, 1-1,5 cm compr., esverdeada a vinácea, ápice truncado. Cincinos 3-5-floros; pedúnculo ausente; bráctea ausente; raque ausente. Flores com tubo do perigônio ca. $25 \mathrm{~mm}$ compr., branco a esverdeado com ápice azulado a lilás, face externa glabra; lobos externos com margem inteira, 13-15 mm compr., 1 posterior e 2 anteriores elípticos a lanceolados, lobos internos com margem inteira, 15-16

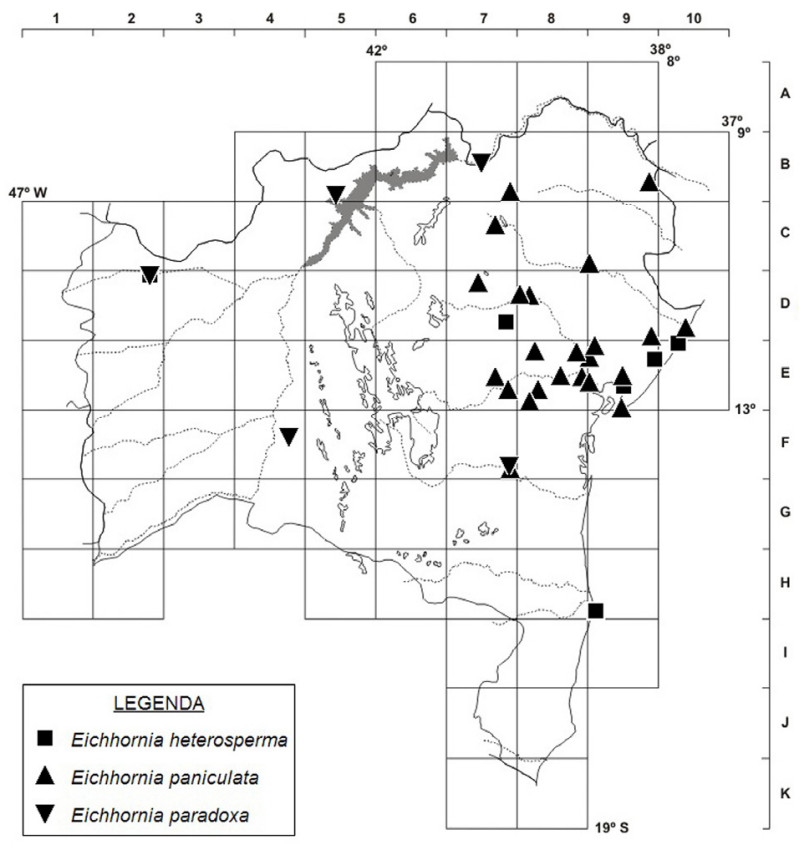

Figura 4. Distribuição de Eichhornia heterosperma, E. paniculata e E. paradoxa no estado da Bahia.

mm compr., 1 anterior largo-elíptico, lilás com duas máculas amarelas na base, e 2 posteriores largoelípticos, lilás; estames 6,3 maiores pubérulos. Cápsulas ca. $15 \mathrm{~mm}$ compr., castanhas; antocarpo castanho-escuro, torcido no ápice. Sementes homomorfas, arredondadas a levemente elipsoides, 0,8-1,3 mm compr., castanho-claras.

Ocorre nas Américas Central e do Sul, desde a Guatemala até o Brasil (Castellanos 1958; Crow 2003). Para o Brasil, Amaral (2014) cita a espécie apenas para o estado da Bahia. Entretanto, nos materiais examinados do gênero Eichhornia foi encontrada uma exsicata da espécie coletada no estado do Rio Grande do Norte. B6, B9, D2, F7: em lagoas temporárias e alagados que margeiam o rio São Francisco e lagoas na porção oeste do estado.

Material examinado - Bom Jesus da Lapa, rodovia para Caetité, 13²2'48”'S, 43¹3'12”'W, 16 abr. 1980, R.M. Harley 21401 (CEPEC, K, NY, SPF); Formosa do Rio Preto, arredores da

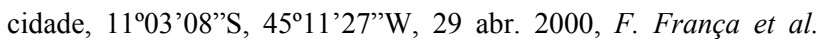
3256 (ALCB, CEPEC, EAC, HUEFS); Jequié, lagoa próxima a entrada da cidade, 1348'16.4”S, 4006'42.1”'W, 21 jun. 2013, D.J.L. Sousa et al. 319 (HUEFS); Juazeiro, 26 jun. 1982, C.N. Horn et al. 529 (IPA); Pilão Arcado, Espinheiro, 0953'34"S, 42³3'59”'W, 18 fev. 2013, D.J.L. Sousa et al. 298 (HUEFS).

Material adicional examinado - BRASIL. RIO GRANDE DO NORTE: Timbaúba dos Batistas, 22 jun. 2010, G.S. Batista \& V. Gomes 336 (EAC).

Eichhornia paradoxa é facilmente reconhecida pelas folhas estreito-lanceoladas, chegando a lineares, e inflorescências em cincinos, sésseis e sem brácteas. Além disso, as flores são lilás e apresentam o lobo da tépala mediana anterior com duas máculas amarelas basais. Gomes (2000) descreve a espécie como possuindo flores actinomorfas, o que a tornaria a única 
espécie no gênero com tal característica. Porém, a zigomorfia das flores de E. paradoxa é bem evidente e típica para o gênero e para a maioria das espécies de Pontederiaceae. Em cada inflorescência, apenas uma flor abre por dia e a antese se inicia em torno das 6:00 horas da manhã, e permanece aberta até cerca das 12:00 horas.

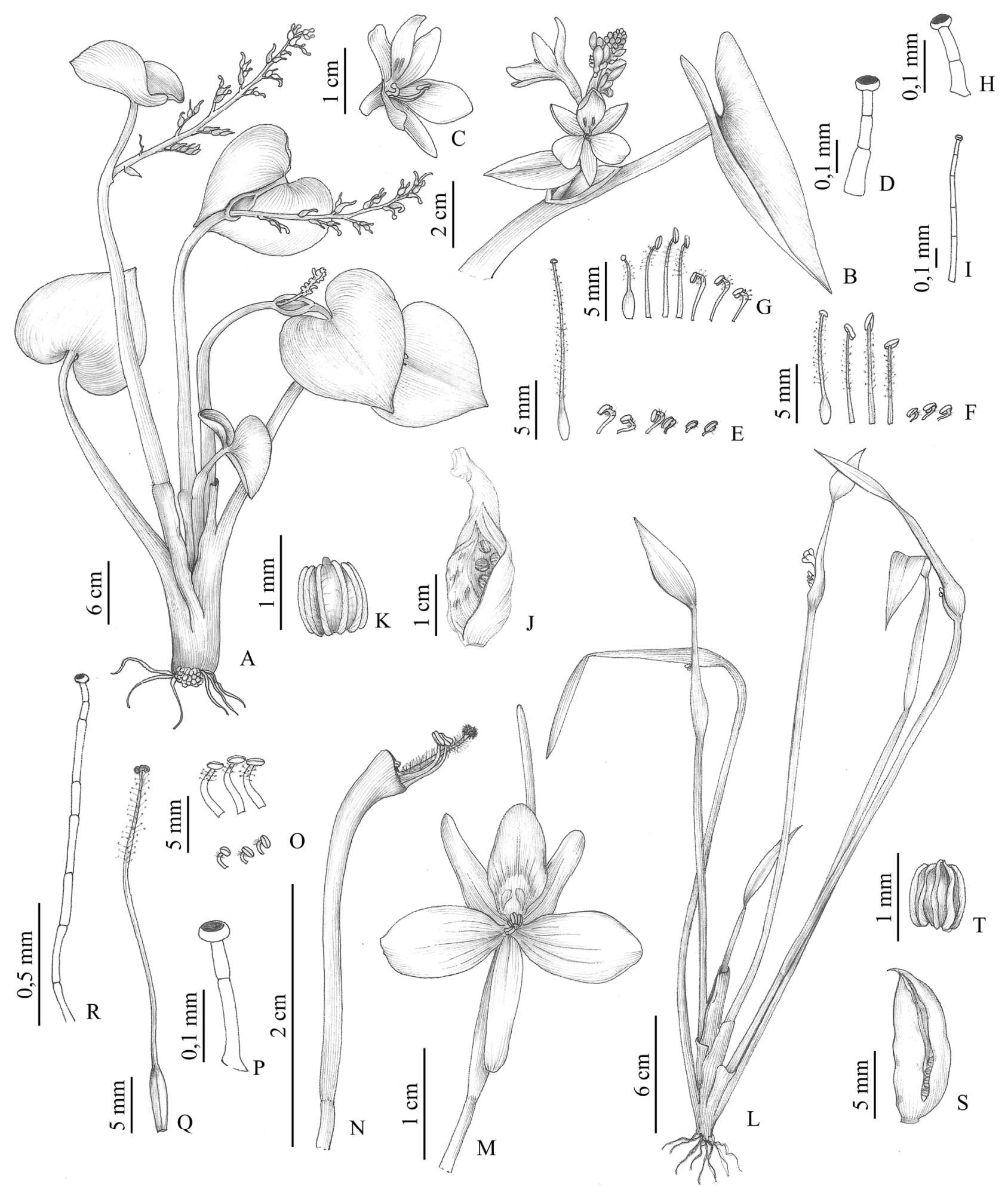

Figura 5. A-K. Eichhornia paniculata: A- hábito; B- ramo florífero; C- flor; D- tricoma da face externa do tubo do perigônio e raque; E- androceu e gineceu de uma flor longistila; F- androceu e gineceu de uma flor medistila; G- androceu e gineceu de uma flor brevistila; H- tricoma dos filetes; I- tricoma dos estiletes; J- fruto com antecio; K- semente. L-T. E. paradoxa: L- hábito; M- ramo florífero; N- flor com lobos retirados; O- androceu; P- tricoma do filete; Q- gineceu; R- tricoma do estilete; S- fruto com antocarpo fendido; T- semente. (A-K-Sousa 193; L-T- Sousa 319) 


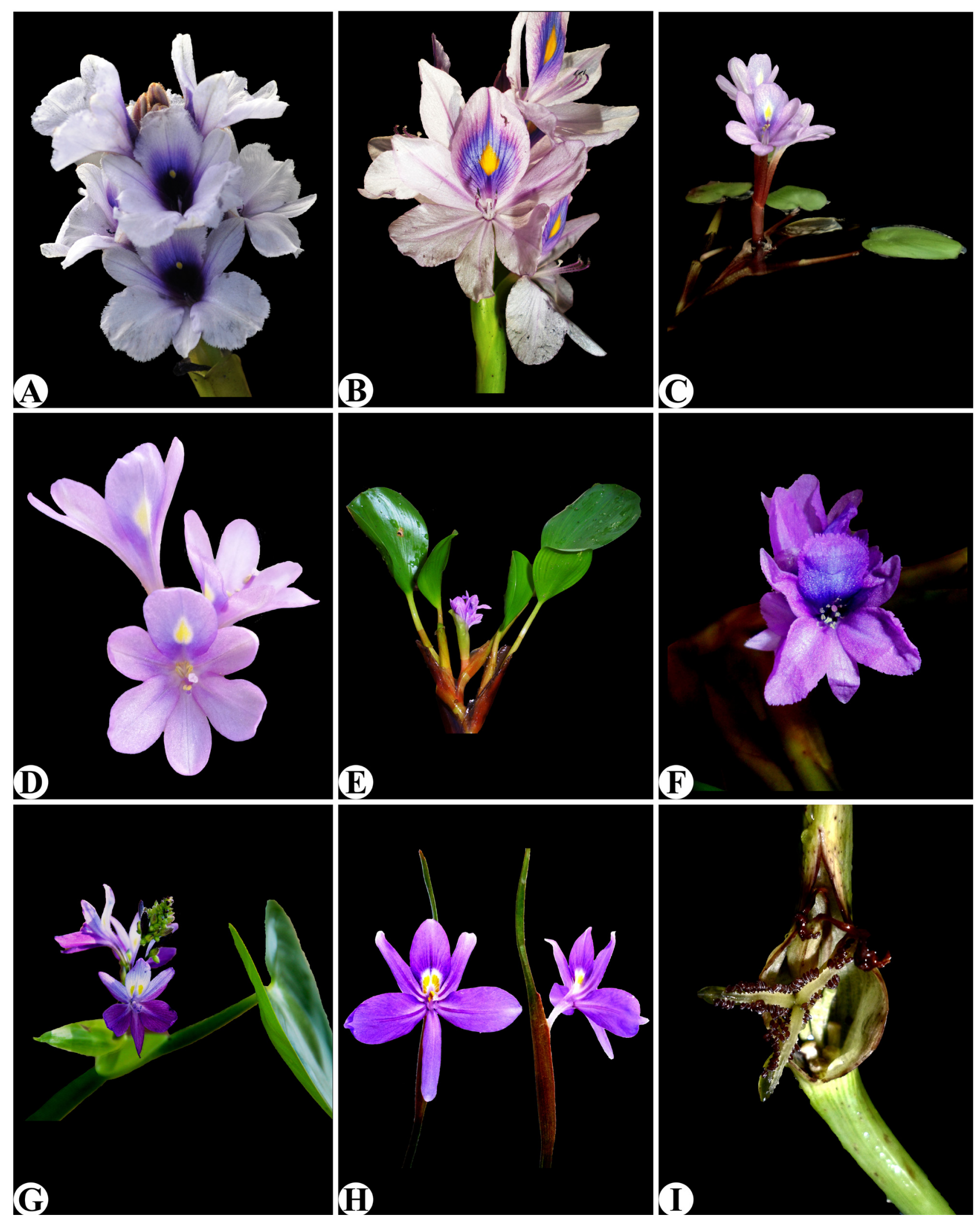

Figura 6. A. Eichhornia azurea. B. E. crassipes. C, D. E. diversifolia. E, F. E. heterosperma. G. E. paniculata. H, I. E. paradoxa.

2. Heteranthera Ruiz \& Pav., Fl. Peruv. Prodr. 9. 1794.

Ervas emergentes, flutuantes fixas ou submersas.

Folhas alternas, dísticas ou espiraladas, ao longo do caule, sésseis ou pecioladas; pecíolos não inflados, cilíndricos; limbos lineares a reniformes; ápice acuminado a arredondado; base cordada a truncada. Inflorescências em cimeiras, 2-14-floras ou flores solitárias; brácteas elípticas a obovais, cimbiformes, parcialmente fechadas; raque glabra ou pubescente. Flores sésseis, lilás, brancas ou amarelas; tubo do perigônio com face externa glabra ou pubescente; lobos externos com margem inteira, 1 posterior estreito-elíptico a largo-elíptico e 2 anteriores elípticos a ovais, lobos internos com margem inteira, 1 anterior 
largo-elíptico a oboval e 2 posteriores ou anteriores elípticos $(3+3$ ou $5+1)$, lobo mediano anterior geralmente com mácula, face abaxial dos lobos acompanhando o indumento do tubo; estames 3, raramente 1 mais 2 estaminódios, filetes cilíndrico ou achatados, brancos a azulados ou amarelos, glabros, pubescentes ou vilosos, anteras heteromorfas, elípticas a sagitadas, basifixas a dorsifixas, azuladas ou amarelas; ovário verde a amarelo, glabro, trilocular, lóculos todos férteis, multiovulados, estilete branco, lilás ou amarelado, glabro, pubescente ou papiloso, estigma capitado a lobado, azulado, esbranquiçado ou amarelado. Cápsulas esverdeadas; antocarpo castanho a enegrecido ou esverdeado, não torcido no ápice, liso, não alado. Sementes elipsoides a subglobosas, costadas.

Heteranthera distingui-se dos demais gêneros da família, especialmente pelo androceu com três estames, sendo um maior fértil e dois menores férteis ou reduzidos a estaminódios, e as anteras que são sempre heteromorfas, frequentemente com forma e cor diferenciadas. $\mathrm{O}$ gênero é bem marcado pela enantiostilia, presente em praticamente todas as espécies. Segundo Horn (1985), as espécies de Heteranthera formariam um grupo monofilético. Entretanto, análises filogenéticas (Ness et al. 2011) vêm demonstrando que, sem a inclusão de Hydrothrix, o gênero é parafilético. São reconhecidas cerca de 12 espécies no gênero, distribuídas pelos continentes americanos e africano, principalmente nas porções tropicais e subtopicais (Horn 1985). Para o Brasil, Amaral (2014) cita sete espécies distribuídas em todas as cinco Regiões. Na Bahia, foram encontradas sete espécies.

\section{Chave para as espécies}

1. Cimeiras com mais de 2 flores; 5 lobos anteriores e 1 posterior $(5+1)$.

2. Limbo foliar linear; bráctea com ápice aristado; flores amarelas 2.6. H. seubertiana

2'. Limbo foliar oval a reniforme, raramente arredondado; bráctea com ápice mucronado; flores brancas ou levemente lilás.

3. Raque da inflorescência pubescente; face externa do tubo do perigônio pubescente; filete do estame maior com tricomas curtos e esparsos

2.1. H. multiflora

3'. Raque da inflorescência glabra; face externa do tubo do perigônio papiloso; filete do estame maior com tricomas longos, no terço inferior.

4. Folhas reniformes, ápice arredondado; flores brancas, lobo anterior totalmente branco 2.4. H. reniformis

4'. Folhas ovais, ápice agudo; flores levemente lilás, lobo anterior levemente lilás com base lilás-escura
1'. Cimeiras 2-floras ou flores solitárias; 3 lobos anteriores e 3 posteriores $(3+3)$ ou 3 anteriores, sendo os laterais externos patentes, os 2 laterais internos horizontais e 1 posterior $(3+2+1)$.

5. Plantas submersas; folhas sésseis, limbo estreito-oboval a linear ....... 2.7. H. zosterifolia

5'. Plantas emergentes ou flutuantes fixas; folhas pecioladas, limbo arredondado a oval.

6. Flores solitárias; bráctea lanceolada, ápice agudo; tubo do perigônio externamente glabro ............................ 2.5. H. rotundifolia

6'. Inflorescências 2-floras; bráctea largo-oval, ápice obtuso a arredondado, levemente retuso; tubo do perigônio externamente pubérulo ........................ 2.2. H. oblongifolia

\subsection{Heteranthera multiflora (Griseb.) C.N.Horn,} Phytologia 59(4): 290. 1986.

Figuras 7A-M, 8 e $13 \mathrm{~A}$.

Erva emergente, rara flutuante fixa, decumbente, $9-15 \mathrm{~cm}$ alt. Folhas submersas não vistas. Folhas emersas ou flutuantes alternas, dísticas, ao longo do caule; pecíolo nunca inflado, 7-12 cm compr., verde, glabro; limbo reniforme a largo-oval, 2,3-3 × 2,5-3,3 $\mathrm{cm}$, glabro, ápice obtuso a arredondado, base cordada, lobos 0,5-0,8 cm compr., levemente imbricados; lígula membranácea, 2-3 cm compr., esverdeada a vinácea, ápice truncado. Cimeiras 5-14-floras; pedúnculo 22,2 cm compr.; bráctea oboval, cimbiforme, $2-3 \mathrm{~cm}$ compr., ápice agudo, mucronado, múcron ca. $3 \mathrm{~mm}$ compr.; raque ca. 4,5 cm compr., verde, pubescente. Flores com tubo do perigônio 5-6 mm compr., verde, face externa pubescente; lobos externos 3,5-5 mm compr., 1 posterior estreito-elíptico a linear, branco a esverdeado, e 2 anteriores elípticos a lanceolados, brancos, lobos internos 4-5 $\mathrm{mm}$ compr., 1 anterior largo-elíptico, branco com base azulada e mácula amarela, e 2 anteriores elípticos $(5+1)$, brancos; estames 3, 1 maior pubérulo, 2 menores vilosos. Cápsulas 10-13 mm compr., esverdeadas; antocarpo castanho a enegrecido. Sementes elipsoides, 0,5-0,8 mm compr., castanhas.

Ocorre nas Américas, dos Estados Unidos até a Argentina (Horn 1985; Crow 2003). Amaral (2014) cita a espécie apenas para o estado de Alagoas. Essa é a primeira citação dessa espécie para a Bahia. G8: em córregos e alagados na Mata Atlântica do sul do estado.

Material examinado - Aurelino Leal, estrada para Itacaré, 14'20'44”S, 39¹3'40”'W, 5 mar. 2013, D.J.L. Sousa et al. 309 (HUEFS); Boa Nova, 22 jan. 2013, D.J.L. Sousa et al. 325 (HUEFS); Buerarema, estrada para São José, 10 jul. 1964, C.M. Magalhães 50 (CEPEC); Coaraci, rio Almada, 14'39'72,7'S, 39³3'50,5'W, 16 dez. 2009, E.A. Rocha et al. 1779 (EAC); Ilhéus, CEPLAC, 13 out. 1981, J.L. Hage et al. 1438 (CEPEC, MBM); Itabuna, BR-101, 14²4'34”S, 39¹9'33”'W, 6 mar. 2013, D.J.L. Sousa et al. 310 (HUEFS); Itajuípe, prox. de União Queimada, 3 maio 1976, T.R. Sodertrom et al. 2183 (CEPEC); Itororó, 
1505'46”S, 4002'21”'W, 1 nov. 2000, J.G. Jardim et al. 3119 (CEPEC, NY).

Heteranthera multiflora foi incluída por Horn (1985) em um complexo que também inclui $H$. reniformis e $H$. peduncularis, sendo o tamanho da inflorescência a principal característica distintiva entre elas. $\mathrm{Na}$ Bahia, os espécimes examinados de $H$. multiflora apresentaram inflorescências maiores do que $4 \mathrm{~cm}$, com a raque sempre ultrapassando o ápice da bráctea e com os estames maiores portando filetes pubérulos, com tricomas curtos. Por tal conjunto de caracteres, a espécie difere de $H$. reniformis, que apresenta as inflorescências menores que $3 \mathrm{~cm}$, com a raque sempre inserida na bráctea e os estames maiores com filetes vilosos na base, característica também encontrada em $H$. peduncularis. Heteranthera multiflora possui flores brancas com o lobo mediano anterior apresentando a base azulada com uma mácula basal amarela. As flores iniciam a antese cerca de 12:00 horas e permanecem abertas até cerca das 17:00 horas.

\subsection{Heteranthera oblongifolia Mart. ex Schult. \&}

Schult. f., Syst. Veg. 7: 1148. 1830.

Figuras 7N-X, 8 e 14B-C.

Erva emergente, decumbente ou ereta, $5-17 \mathrm{~cm}$ alt. Folhas submersas não vistas. Folhas emersas alternas, dísticas, ao longo do caule; pecíolo nunca inflado, 3,5-12 × 0,1-0,4 cm, verde, glabro; limbo largo-elíptico a oval, 1,6-6,2 × 1-4 cm, glabro, ápice agudo ou obtuso, base arredondada a cordada, lobos 0,2-0,6 cm compr., imbricados ou não; lígula membranácea, ca. $1,7 \mathrm{~cm}$ compr., vinácea, ápice truncado a levemente retuso. Cimeiras 2-floras; pedúnculo 1-3,8 cm compr.; bráctea largo-oboval, cimbiforme, 1,2-2 cm compr., ápice obtuso a levemente retuso, mucronado, múcron 0,5-2 $\mathrm{mm}$ compr.; raque $0,3-1,5 \mathrm{~cm}$ compr., verde, glabra. Flores com tubo do perigônio 14-29 mm compr., verde, face externa pubérula no ápice; lobos externos 5-8 mm compr., 1 posterior elíptico a largo-elíptico, branco ou lilás, e 2 anteriores elípticos a largoelípticos, brancos ou lilás, lobos internos 6-9,5 mm compr., 1 anterior largo-elíptico, branco ou lilás com mácula amarela na base, e 2 posteriores elípticos a largo-elípticos $(3+3)$, brancos ou lilás; estames 3,1 maior pubérulo, 2 maiores glabros a pubérulos. Cápsulas 16-20 mm compr., esverdeadas; antocarpo castanho a enegrecido. Sementes oblongas, ca. 0,8 mm compr., castanhas.

Ocorre nas Américas do Norte (México), Central e do Sul, inclusive nas ilhas do Caribe (Horn 1985; Novelo \& Ramos 1998; Crow 2003). No Brasil, está restrita ao Nordeste, sendo citada para a Bahia, Ceará e Paraíba (Amaral 2014). B7, B8, C7, C8, D2, D7, E8, F4, F5, F6: em corpos d'água temporários e açudes nas áreas semiáridas e mais raramente em alagados no oeste do estado.

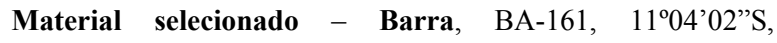
4308'46"W, 16 fev. 2013, D.J.L. Sousa et al. 270 (HUEFS); Bendengó, em direção a Uauá, 0957'30"S, 39¹1'19'W, 23 fev. 2000, A.M. Giulietti et al. 1768 (HUEFS); Bom Jesus da Lapa, estrada para Malhada, 1324'13"S, 4321'43”'W, 11 fev. 2000, L.P. Queiroz et al. 5882 (HRB, HUEFS); Euclides da Cunha, estrada para Tucano, 10²8'36”S, 3901'00”'W, 21 fev. 2000, A.M. Giulietti

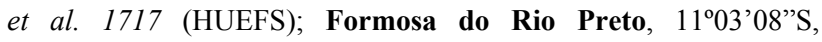
45'11'27'’W, 29 abr. 2000, F. França et al. 3251 (CEPEC, HRB, HUEFS); Iaçu, 11 fev. 1997, R. M. Harley et al. PCD 5495 (CEPEC, HUEFS, MBM); Jequié, entrada da cidade, 21 jun. 2013, D.J.L. Sousa et al. 317 (HUEFS); Juazeiro, estrada para Sobradinho, 26 jun. 1982, C.N. Horn et al. 526 (IPA); Maracás, estrada para Nova Planaltina, 1324'54”S, 40²4'21'W, 2 abr. 2013, D.J.L. Sousa et al. 333 (HUEFS); Marcolino Moura, estrada para Rio de Contas, 13³1'68'S, 41³5'88'W, 19 dez. 1997, M. Alves et al. 1163 (PEUFR); Miguel Calmon, estrada para Jacobina,

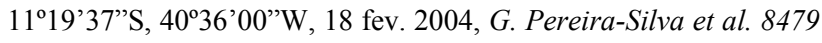
(HUEFS); Paramirim, Barragem do Zabumbão, 13²6'06”'S, 42¹2'39"W, 6 fev. 1997, S. Atkins et al. PCD 5171 (CEPEC, HUEFS, MBM); Remanso, Vila Cardoso, 19 fev. 2013, D.J.L. Sousa et al. 304 (HUEFS); Rio de Contas, 13\%44'28'S, 41'34'59"W, 26 jan. 2001, R.M. Harley et al. 34074 (HUEFS); Senhor do Bonfim, Carrapichel, 10²2'47'S, 4009'23'W, 28 jul. 2005, P.D. Carvalho et al. 154 (HUEFS); Sobradinho, 09²8'56"S, 4049'16"W, 22 set. 2009, F.S. Gomes \& E. Melo 270a (ALCB). Sem localidade precisa: C.F.P. Martius 2366 (M); Serra de Jacobina, 1837, J.S. Blanchet 2678 (K); estrada entre Joazeiro e Sobradinho, 26 jun. 1982, C.N. Horn et al. 526 (IPA).

Material adicional examinado - BRASIL. CEARÁ: Caridade, lagoa Contendas, 21 jun. 2008, D.J.L. Sousa 19 (EAC).

Heteranthera oblongifolia pode ser reconhecida pelas inflorescências bifloras, onde as flores podem se abrir simultaneamente ou apenas uma em cada dia subsequente. Essa distribuição das flores, pode confundi-la com espécies unifloras do gênero, como $H$. rotundifolia, da qual ela se distingue pelo formato da bráctea e face externa do tubo do perigônio pubescente. As flores em $H$. oblongifolia podem variar de cor, na mesma população, de lilás a brancas, com o lobo anterior central com duas máculas basais de cor amarela, que podem apresentar uma grande variação nas suas dimensões e ser bastante reduzidas. As flores iniciam a antese em torno das 7:00 horas da manhã e permanecem abertas até cerca de 12:00 horas.

\subsection{Heteranthera peduncularis Benth., Pl. Hartw. 25.} 1840.

Figuras 9A-M, 10 e 14D.

Erva emergente, rara flutuante fixa, decumbente, $7-10 \mathrm{~cm}$ alt. Folhas submersas não vistas. Folhas emersas ou flutuantes alternas, dísticas, ao longo do caule; pecíolo nunca inflado, 5-9 × 0,2-0,3 cm, verde, glabro; limbo oval, raramente arredondado, 2,8-3 $\times$ 2,5-2,9 cm, glabro, ápice obtuso a agudo, base cordada, lobos 0,4-0,5 cm compr., não imbricados; lígula, membranácea, 2,5-3 cm compr., hialina a vinácea, ápice truncado. Cimeiras 5-7-floras; pedúnculo ca. $0,9 \mathrm{~cm}$ compr.; bráctea oboval, 


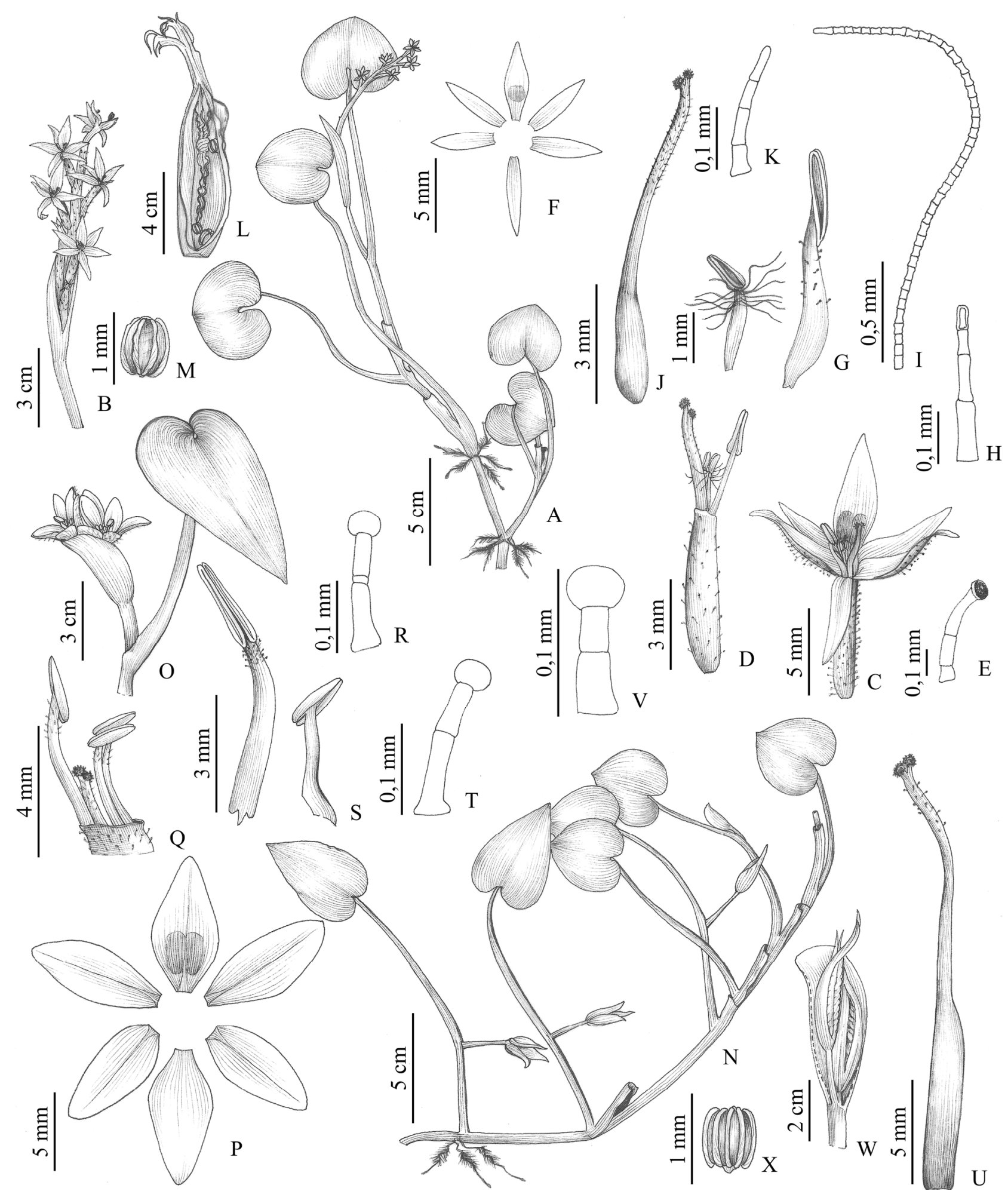

Figura 7. A-M. Heteranthera multiflora: A- hábito; B- inflorescência; C- flor; D- flor com os lobos retirados; E- tricoma da porção externa das flores e raque; F- detalhe da disposição dos lobos (lobos separados do tubo); G- androceu, com o estame maior e um dos estames menores; H- tricoma do filete do estame maior; I- tricoma dos filetes dos estames menores; J- gineceu; K- tricoma dos estiletes; L- fruto com antocarpo fendido; M- semente. N-X. H. oblongifolia: N- hábito; O- ramo florífero; P- detalhe da disposição dos lobos (lobos separados do tubo); Q- ápice do tudo do perigônio com os lobos retirados; R- tricoma da face externa do tubo do perigônio; S- androceu, com o estame maior e um dos estames menores; T- tricoma dos filetes; U- gineceu; W- frutos envolvidos pela bráctea e antocarpos fendidos; X-semente. (A-M-Sousa 309; N-X-Sousa 270)

cimbiforme, ca. $3 \mathrm{~cm}$ compr., ápice agudo, mucronado, múcron ca. $2 \mathrm{~mm}$ compr.; raque ca. 4,5 cm compr., verde, glabra. Flores com tubo do perigônio 6-8 mm compr., verde, face externa papilosa na porção apical e na inserção da raque; lobos externos 4,5-5 mm compr., 1 posterior estreito-elíptico a linear, levemente lilás, e 2 anteriores elípticos, levemente lilás, lobos internos 4-5 $\mathrm{mm}$ compr., 1 anterior largo-elíptico a oval, levemente 


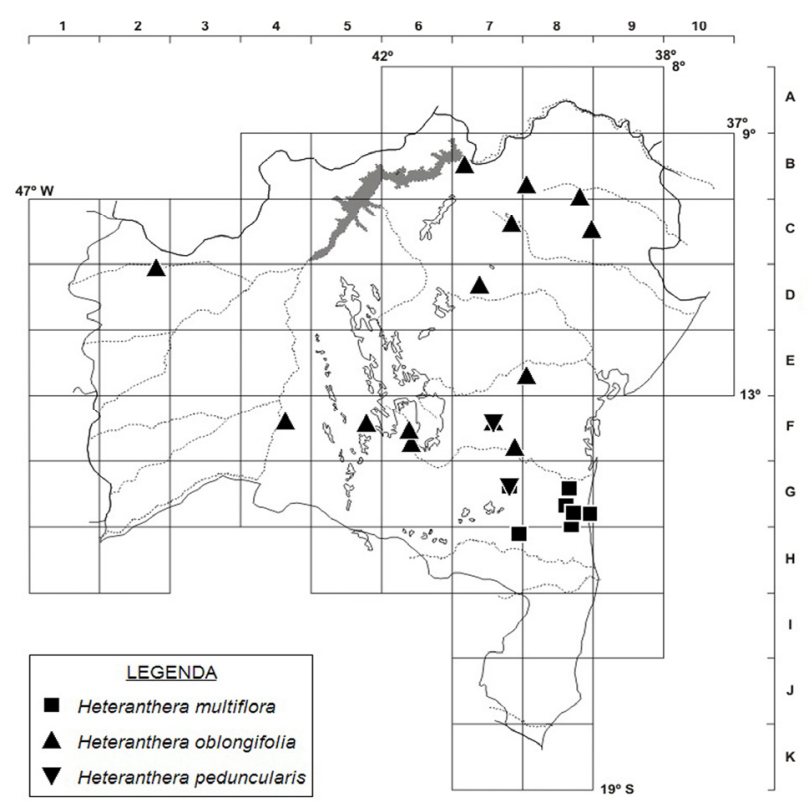

Figura 8. Distribuição de Heteranthera multiflora, H. oblongifolia e $H$. peduncularis no estado da Bahia.

lilás com base lilás-escura, e 2 anteriores elípticos $(5+$ 5), lilás; estames 3, 1 maior com tricomas longos no terço inferior, 2 menores vilosos. Cápsulas ca. $13 \mathrm{~mm}$ compr., esverdeadas; antocarpo castanho a enegrecido. Sementes elipsoides, ca. 0,8 mm compr., castanhas.

Ocorre nas Américas, com registros desde os Estados Unidos até a Argentina (Schulz 1942; Castellanos 1958; Novelo \& Ramos 1998). Amaral (2014) não cita a espécie para o país, apesar de Castellanos (1958) tê-la registrado para a Paraíba e Rio Grande do Sul. F7, G7: tem poucas coletas, mas pode ser encontrada em pequenos lagos e córregos, em áreas semiáridas do estado.

Material examinado - Boa Nova, córrego próximo à estrada, 14²3'03.8”, 40 4011'15.1'W, 22 jun. 2013, D.J.L. Sousa et al. 327 (HUEFS); Maracás, estrada para Nova Planaltina, 1324'54”S, 40²4'21'”, 2 abr. 2013, D.J.L. Sousa et al. 334 (HUEFS).

Material adicional examinado - MÉXICO. AGUASCALIENTES: Aguascalientes, 1839, M. Hartweg 226 (K).

Heteranthera peduncularis foi descrita por Horn (1985) como possuindo as folhas com ápice agudo a acuminado e os estames maiores com filetes glabros. A análise da imagem do material-tipo confirmou o formato do ápice foliar, porém não é suficiente para confirmar o indumento do filete. Os espécimes da Bahia identificados como Heteranthera peduncularis apresentam ápice das folhas de obtuso a agudo e o estame maior com filete viloso. Essa identificação está baseada nas descrições de Schulz (1942) e Castellanos (1958), que se referem à espécie como possuindo flores levemente lilás, com o filete do estame maior viloso na base e o filete dos estames menores vilosos no ápice. Com base nos espécimes da Bahia, H. peduncularis pode ser caracterizada também pela raque da inflorescência glabra e a porção externa das flores com papilas, características que não haviam sido mencionadas naquelas descrições. As flores iniciam a antese em torno das 7:00 horas da manhã e permanecem abertas até cerca de 12:00.

\subsection{Heteranthera reniformis Ruiz \& Pav., Fl. Peruv.} 1: 43; pl. 71, f.a. 1798.

Figuras 9N-X, 10 e 14E.

Erva emergente, rara flutuante fixa, decumbente, 8-20 cm alt. Caule verde, glabro; entrenós 1,5-6 cm compr., verdes, glabros. Folha submersa não vista. Folha emersa ou flutuante alterna dística, ao longo do caule; pecíolo nunca inflado, $14-30 \times 0,3-0,7 \mathrm{~cm}$, verde, glabro; limbo reniforme a largo-oval, 4,5-7,2 $\times$ 4,3-8 cm, verde, campilódromo, glabro, ápice obtuso a arredondado, base cordada, lobos $0,5-1,5 \mathrm{~cm}$ compr., levemente imbricados ou não; lígula, membranácea, 4$4,9 \mathrm{~cm}$ compr., esverdeada, ápice truncado. Cimeiras 3-7-floras; pedúnculo 0,5-0,7 cm compr., verde, glabro; bráctea estreito-oboval, cimbiforme, 1,7-3 cm compr., verde, ápice agudo, mucronado, múcron 1-2 $\mathrm{mm}$ compr.; raque ca. 2,9 $\mathrm{cm}$ compr., verde, glabra. Flores com tubo do perigônio 6-8 mm compr., verde, face externa papilosa na porção apical e na inserção da raque; lobos externos 4,5-5 $\mathrm{mm}$ compr., 1 posterior estreito-elíptico a linear, branco a esverdeado, e 2 anteriores elípticos, brancos, lobos internos 4-5 mm compr., 1 anterior largo-elíptico a oval, branco, mácula ausente, e 2 anteriores elípticos $(5+5)$, brancos; estames 3, 1 maior com tricomas longos no terço inferior, 2 menores vilosos. Cápsulas 9-12 $\mathrm{mm}$ compr., esverdeadas; antocarpo castanho a enegrecido. Sementes elipsoides a ovaladas, ca. 0,9 $\mathrm{mm}$ compr., castanhas.

Tem distribuição nas Américas, desde os Estados Unidos até a Argentina (Schulz 1942; Horn 1985; Novelo \& Ramos 1998; Crow 2003). Amaral (2014) cita a espécie para as cinco Regiões brasileiras. No Nordeste, sua ocorrência está restrita à Bahia. D7, D8, E8: em corpos d'água temporários ou permanentes, nas regiões central e norte, em áreas de Caatinga.

Material selecionado - Anguera, $12^{\circ} 13^{\prime} 27^{\prime}$ 'S, 39 $05^{\circ} 45^{\prime \prime} \mathrm{W}$, 9 ago. 2012, D.J.L. Sousa et al. 192 (HUEFS); Cabaceiras do Paraguaçu, 12³7'95,7'S, 3857'67,7'”, 7 ago. 2012, L.Y.S.

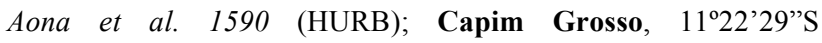
4000'38"W, 9 ago. 2012, D.J.L. Sousa et al. 204 (HUEFS);

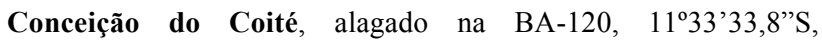
$39^{\circ} 16^{\prime} 33,0$ "W, 9 ago. 2012, D.J.L. Sousa et al. 210 (HUEFS); Cruz das Almas, Fonte do Doutor, 8 abr. 2008, L.Y.S. Aona et al. 1078 (HURB); Jacobina, Barracão de Cima, 11\%01'07'S, 40³2'43”'W, 6 jul. 1996, H.P. Bautista et al. PCD 3462 (ALCB, HUEFS); Piritiba, $11^{\circ} 43^{\prime}$ S 403' 'W, 31 maio 1980, L.R. Noblick 1882 (ALCB, HUEFS).

Heteranthera reniformis apresenta folhas largoovais a reniformes e inflorescências que não ultrapassam $3 \mathrm{~cm}$ de comprimento, sendo o pedúnculo bastante curto, o que dá muitas vezes a impressão das inflorescências serem sésseis. Nos espécimes examinados da Bahia, as flores são totalmente brancas e sem mácula no lobo mediano anterior. Além disso, os 


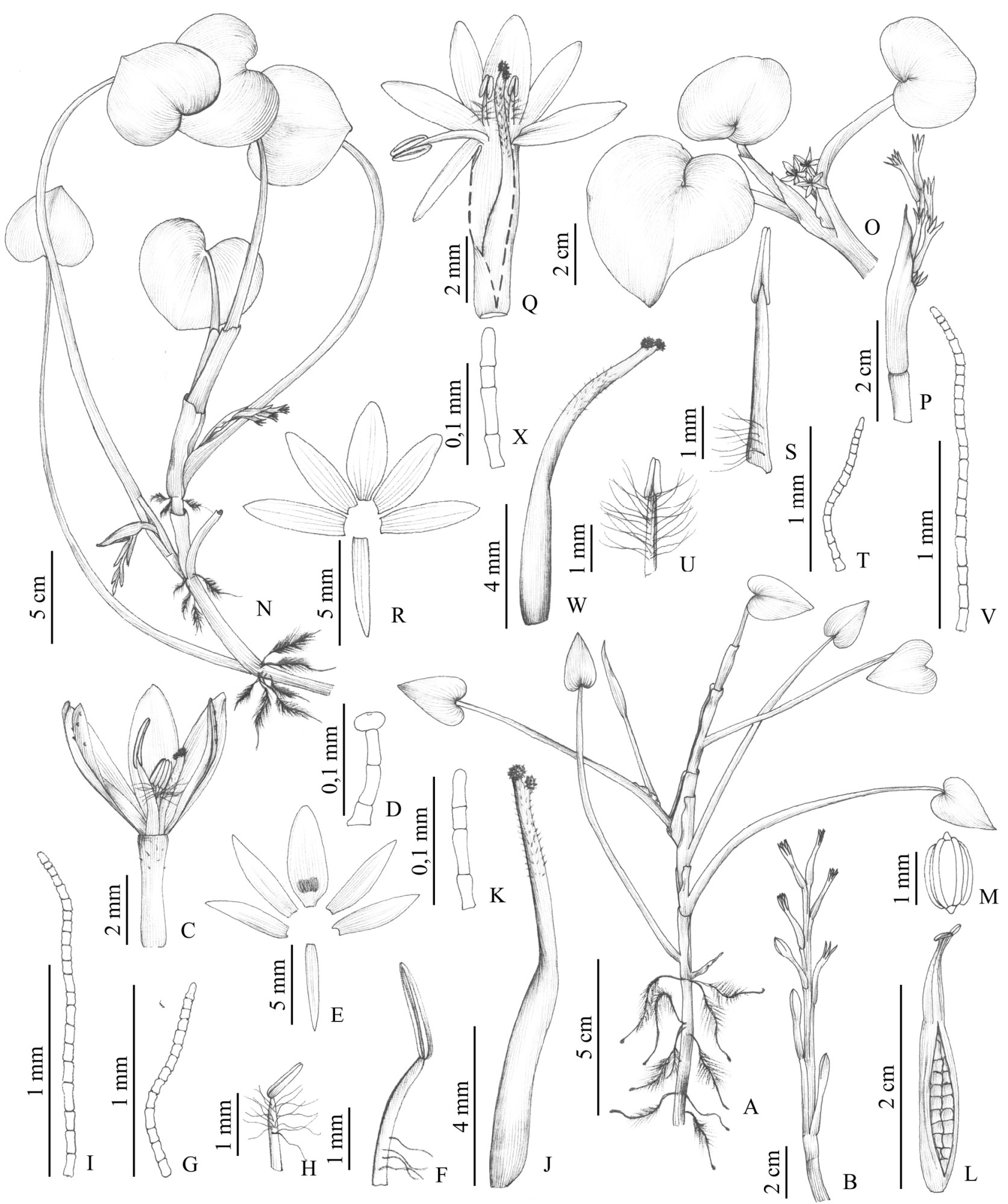

Figura 9. A-M. Heteranthera peduncularis: A- hábito; B- inflorescência com a bráctea retirada; C- flor com o lobo posterior inferior retirado; D- tricoma da face externa do tubo do perigônio; E- detalhe da disposição dos lobos (retirados do tubo do perigônio); F- estame maior; G- tricoma do filete do estame maior; H- estame menor; I- tricoma dos filetes dos estames menores; J- gineceu; K- tricoma dos estiletes; L- fruto com antocarpo fendido; M- semente. N-X. H. reniformis: N- hábito; O- porção apical com detalhe no ramo florífero; P- inflorescência; Q- flor com corte longitudinal no tubo do perigônio; R- detalhe da disposição dos lobos (retirados do tubo do perigônio); S- estame maior; T- tricoma do filete do estame maior; U- estame menor; V-tricoma dos filetes dos estames menores; W- gineceu; X-tricoma dos estiletes. (A-M- Sousa 327; N-X-Sousa 204)

espécimes da Bahia apresentam as flores com os lobos de ápice obtuso a arredondado, com papilas na face externa do tubo do perigônio e na face externa dos lobos. As flores entram em antese em torno das 7:00 horas da manhã e permanecem abertas até cerca das 12:00 horas. 
2.5. Heteranthera rotundifolia (Kunth) Griseb., Cat. Pl. Cub.: 252. 1866.

Figuras $10,11 \mathrm{~A}-\mathrm{G}$ e $14 \mathrm{~F}$.

Erva emergente ou flutuante fixa, ereta ou decumbente, 9-17 $\mathrm{cm}$ alt. Folhas submersas não vistas. Folha emersas ou flutuantes alternas, dísticas, basais ou ao longo do caule; pecíolo nunca inflado, 3-7 $\times$ 0,1-0,2 cm, verde, glabro; limbo largo-elíptico a arredondado, 1,5-3,6 × 0,7-2,9 cm, glabro, ápice obtuso a arredondado, base truncada a arredondada; lígula, membranácea, 2,5-4 cm compr., hialina, ápice truncado. Flores solitárias; pedúnculo $1,5-0,4 \mathrm{~cm}$ compr.; bráctea elíptica a estreito-oboval, cimbiforme, 1,4-2,5 cm compr., ápice agudo, mucronado, múcron 0,5-1,1 mm compr.; raque ausente; tubo do perigônio 15-18 mm compr., verde, face externa glabra; lobos externos 10-14 mm compr., 1 posterior largo-elíptico a lanceolado, branco ou lilás, e 2 laterais anteriores elípticos, brancos ou lilás com ápice azulado, patentes, lobos internos $10-14 \mathrm{~mm}$ compr., 1 anterior estreitoelíptico a triangular, com duas projeções lilás na base, branco ou lilás, e 2 horizontais elípticos $(3+2+1)$, brancos ou lilás; estames 3,1 maior pubérulo, 2 menores pubérulos. Cápsulas 10-25 $\mathrm{mm}$ compr., esverdeadas; antocarpo esverdeado a castanho. Sementes oblongas a ovadas, ca. $0,8 \mathrm{~mm}$ compr., castanhas.

Ocorre nas Américas do Norte (México), Central (Nicarágua) e do Sul (Bolívia, Equador, Peru e Brasil) (Horn 1985; Novelo \& Ramos 1998; Crow 2003). Para o Brasil, Amaral (2014) cita a espécie para o Nordeste e Sudeste, principalmente para as áreas cobertas pelo domínio da Mata Atlântica. Diferentemente, as populações estudadas da Bahia estão associadas às regiões semiáridas. B5, B6, B7, C6, C7, C8, C9, D5, E7, E8, F6, F7, G5: em corpos d'água temporários, açudes e alagados nas margens de estradas.

Material selecionado - Abaíra, $13^{\circ} 14^{\prime} \mathrm{S}, 41^{\circ} 41^{\prime} \mathrm{W}, 31$ jan. 1992, D.J.N. Hind et al. H51407 (SPF); Barra, BA-161,

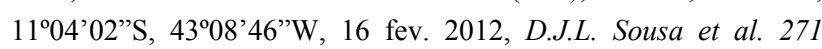
(HUEFS); Bendegó, em direção a Uauá, 0957’30”S, 39¹1'19”W, 23 fev. 2000, A.M. Giulietti et al. 1764 (HUEFS); Brumado, estrada para Livramento, 12 dez. 1984, G.P. Lewis et al. 6722 (K, SPF); Caetité, Baixa Grande, 1404'03"S 42³8'12"W, 9 fev. 1997, B. Stannard et al. PCD5297 (CEPEC, HUEFS, SPF); Campo Alegre de Lourdes, estrada para Remanso, 09³6'02"S, 4252'44”W, 17 abr. 2004, T.S. Nunes et al. 1033 (HUEFS); Capim Grosso, 11'20'41”S, 3957'33”W, 9 ago. 2012, D.J.L. Sousa et al. 209 (HUEFS); Casa Nova, estrada para Remanso, 09²16'S,

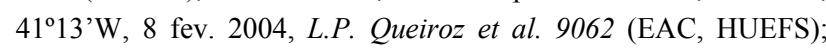
Curaçá, $09^{\circ} 51^{\prime}$ S, $39^{\circ} 59^{\prime}$ 'W, 19 ago. 1983, G.C.P. Pinto et al. 22/83 (HRB); Euclides da Cunha, estrada para Tucano, 10²8'46"S, 3901'16"W, 21 fev. 2000, A.M. Giulietti et al. 1715 (HUEFS); Gentio do Ouro, caminho para Santo Inácio, 11\%06’24”S, 4243'14"W, 24 jun. 1996, M.L. Guedes et al. PCD3006 (CEPEC, HUEFS, SPF); Guanambi, 15 jan. 1997, G. Hatschbach et al. 65812 (MBM); Iaçu, estrada para Itaeté, 11 fev. 1997, A.M.
Giulietti et al. 5484 (HRB, HUEFS, K, SPF); Jacobina, Campo Formoso, 19 jul. 1978, Andrade-Lima 78-8449 (IPA); Jaguarari, fazenda Muquem, $09^{\circ} 25^{\prime} 25^{\prime}$ 'S, 40²5'43”W, 27 nov. 2010, E. Melo et al. 8923 (HUEFS); Juazeiro, estrada para o Senhor do Bonfim, $10^{\circ} 00^{\prime} \mathrm{S}, 42^{\circ} 12^{\prime} \mathrm{W}, 27$ mar. 2004, A.M. Giulietti et al. 2476 (HUEFS); Macaúbas, estrada para Caetité, 21 abr. 1996, G. Hatschbach et al. 65155 (MBM); Maracás, 13²4'54"S, 40²4'21”'W, 2 abr. 2013, D.J.L. Sousa et al. 335 (HUEFS); Marciolinio Souza, estrada para João Amaro, 11 fev. 1997, A.M. Giulietti et al. PCD5505 (CEPEC, HRB, HUEFS); Milagres, estrada para Iaçu, $12^{\circ} 53^{\prime} \mathrm{S}, 39^{\circ} 49^{\prime} \mathrm{W}, 31$ jan. 2000, A.M. Giulietti et al. 1972 (HUEFS); Nossa Senhora do Livramento, 13²32'S, 41 ${ }^{\circ} 57^{\prime}$ W, 11 jan. 2000, A.M. Giulietti et al. 1697 (HUEFS); Pilão Arcado, Espinheiro, 0953'59'S, 42³3'59'W, 29 fev. 2000, M.L. Guedes et al. 7013 (HRB, HUEFS, NY, SPF); Riachão do Jacuípe, fazenda São Pedro, $11^{\circ} 22^{\prime}$ S, 39 $49^{\circ}$ 'W, 10 jul. 1985, L.R. Noblick et al. 4055 (CEPEC, HUEFS); Rio de Contas, 13\%44'28”'S, 41'34'59'W, 26 jan. 2001, R.M. Harley et al. 54075 (HUEFS); Senhor do Bonfim, $09^{\circ} 55^{\prime} \mathrm{S}, 40^{\circ} 15^{\prime} \mathrm{W}, 25$ fev. 1974 , R.M. Harley et al. 16342 (CEPEC, IPA, NY); Sento Sé, Brejo da Brazida, fazenda da Mariluzi, $10^{\circ} 20^{\prime} 19,80^{\prime} \mathrm{S}, 41^{\circ} 45^{\prime} 58,50^{\prime \prime} \mathrm{W}, 15$ mar. 2012, V.M. Cotarelli et al. 1524 (HVASF); Sobradinho, 09'28'57'S, 40'49'16”'W, 23 set. 2009, E. Melo et al. 6513 (HUEFS); Tucano, estrada para Araci, 20 fev. 1992, A.M. Carvalho et al. 3847 (CEPEC, NY); Utinga, estrada para Barra, 15 fev. 2013, D.J.L. Sousa et al. 240 (HUEFS).

Heteranthera rotundifolia é similar morfologicamente a $H$. limosa (Sw.) Willd., principalmente pelas flores solitárias. As diferenças entre elas estão relacionadas com a organização das flores, especialmente a posição dos lobos das tépalas, que em $H$. limosa, estão dispostos em 2 lobos externos laterais e 1 interno anterior mediano (todos denominados de anteriores); e 2 lobos internos laterais e 1 externo posterior mediano (todos denominados de posteriores), enquanto em $H$. rotundifolia são 2 lobos externos laterais, patentes e 1 interno anterior mediano, com o ápice agudo; e os 2 lobos internos são horizontais (diferente da posição posterior em $H$. limosa) e 1 externo posterior, bem mais largo que os outros. Como essas diferenças são mais visíveis em campo ou em material em cultivo, muitos espécimes de $H$. rotundifolia herborizados estão erroneamente identificados como $H$. limosa. Tal situação tem levado muitos autores, inclusive Amaral (2014) a colocar essa última espécie como possuindo uma ampla distribuição no país. Horn (1985), ao descrever H. rotundifolia, refere-se à presença de duas projeções na base do lobo mediano anterior. Esse foi o principal caráter utilizado para distinguir as duas espécies na análise do material herborizado. A partir desses resultados, H. limosa está mais restrita ao domínio do Pantanal brasileiro e regiões adjacentes, não ocorrendo no Nordeste, enquanto $H$. rotundifolia está distribuída principalmente no Nordeste brasileiro, incluindo o estado da Bahia. As flores nessa espécie iniciam a antese em torno das 7:00 horas da manhã e permanecem abertas até cerca das 12:00 horas. 
2.6. Heteranthera seubertiana Solms, Monogr. Phan. 4: 518. 1882.

Figuras 10,11H-R e 14G-H.

Erva submersa ou emergente, ereta, $10-25 \mathrm{~cm}$ alt. Folhas submersas ou emergentes alternas, ao longo do caule quando submersa, ou basais quando emergente, sésseis; limbo linear, 3,5-20 × 0,2-0,7 cm, glabro, quando emergente pubérulo, ápice acuminado, base truncada; lígula membranácea, $0,1-0,5 \mathrm{~cm}$ compr., esverdeada, ápice truncado a acuminado. Cimeiras 510-floras; pedúnculo 1,8-5,4 cm compr.; bráctea largoelíptica, cimbiforme, $1,3-2,3 \mathrm{~cm}$ compr., ápice aristado, arista ca. 6,5 $\mathrm{mm}$ compr.; raque $4-9 \mathrm{~cm}$ compr., verde, pubérula. Flores com tubo do perigônio 6-12 mm compr., verde, face externa pubérula; lobos externos ca. $7 \mathrm{~mm}$ compr., 1 posterior elíptico a linear, amarelo a esverdeado, raramente lilás, e 2 anteriores estreito-obovais, amarelos, com base vinácea, raramente lilás com base vinácea, lobos internos ca. 7,8 $\mathrm{mm}$ compr., 1 anterior elíptico a oboval, amarelo com base vinácea, raramente lilás com base vináceae, e 2 anteriores elípticos $(5+1)$, amarelos com base vinácea, raramente lilás com base vinácea; estames 3 , glabros. Cápsulas 9-13 mm compr., esverdeadas; antocarpo esverdeado. Sementes elipsoides a subglobosas, 0,4 0,5 mm compr., castanho-escuras.

Tem distribuição registrada para a América do Norte (México) e para a América do Sul, na Venezuela (Horn 1985; Novelo \& Ramos 1998) e Brasil, onde é considerada por Horn (1985) como restrita ao Nordeste brasileiro. Amaral (2014) cita a espécie com ocorrência apenas para o estado da Bahia. B5, B6, B7, B8, B9, E6, E8, F3, F4, G8: em rios ou riachos de águas calmas, e em ambientes lênticos, nos domínios da Caatinga, Mata Atlântica e Cerrado.

Material selecionado - Cachoeira, Roncador, 12 $2^{\circ} 1^{\prime} 59^{\prime \prime} \mathrm{S}$, 3904'59'W, 1 out. 1980, Grupo Pedra do Cavalo 868 (ALCB, CEPEC, EAC, HRB, HUEFS); Casa Nova, fazenda Santarém/rio Sobradinho, $09^{\circ} 36^{\prime} 38^{\prime \prime}$ 'S $41^{\circ} 19^{\prime} 43^{\prime \prime} \mathrm{W}, 10$ out. 2004, L.P. Queiroz et al. 9665 (HUEFS); Correntina, Vale do Rio Formoso, 13²40'S $44^{\circ} 25^{\prime}$ W, 24 abr. 1980, R.M. Harley et al. 21719 (CEPEC, K, NY, SPF); Curaçá, fazenda Ouricuri, $09^{\circ} 21^{\prime} 09^{\prime \prime}$ 'S, 39 396'09’W, 23 abr. 2006, J.A. Siqueira-Filho et al. 1624 (HVASF); Glória, Lagoa de Itaparica, $09^{\circ} 02^{\prime} 22^{\prime \prime}$, $38^{\circ} 18^{\prime} 01^{\prime \prime} \mathrm{W}, 19 \mathrm{jan} .2012$, V.M. Cotarelli et al. 1201 (HVASF); Ilhéus, Banco do Pedro, 12 jan. 2005, R.N. Querino et al. 85 (HUEFS); Juazeiro, estrada para Sobradinho, 26 jun. 1982, C.N. Horn et al. 530 (IPA, K); Remanso, Major, 09 $38^{\prime} 09^{\prime}$ 'S, $42^{\circ} 06^{\prime} 41^{\prime \prime} \mathrm{W}, 3$ jul. 2003, L.P. Queiroz et al. 7879 (HUEFS); Ubaitaba, Rio de Contas, $14^{\circ} 18^{\prime} 55^{\prime \prime}$ 'S, $39^{\circ} 15^{\prime} 57^{\prime \prime}$ 'W, 5 mar. 2013, D.J.L. Sousa et al. 308 (HUEFS); Utinga, 1839, J.S. Blanchet 2740 (K).

Heteranthera seubertiana é distinta de todas as outras espécies do gênero que ocorrem na Bahia por suas flores predominantemente amarelas e folhas lineares. Pode ocorrer como planta submersa, com folhas glabras ao longo de todo o caule $\mathrm{e}$ comprimento maior do que as folhas emergentes, ou como plantas emergentes, com folhas praticamente basais, pubérulas e com comprimento menor. Horn

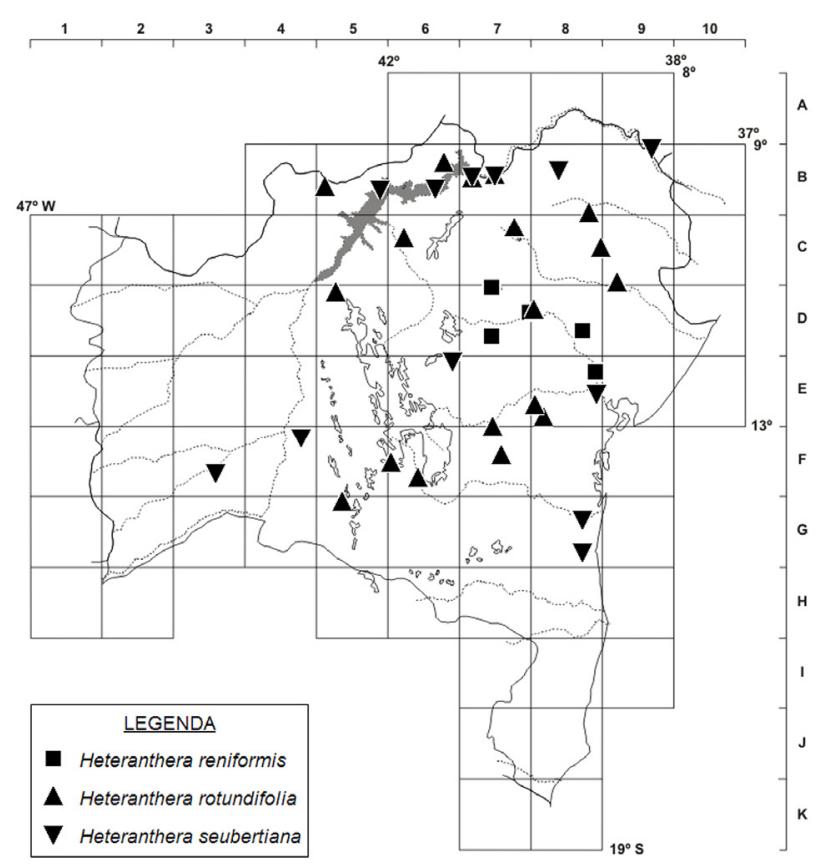

Figura 10. Distribuição de Heteranthera reniformis, H. rotundifolia e H. seubertiana no estado da Bahia.

(1985) cita a ocorrência de populações com flores lilás apenas para a Venezuela e para o México. $\mathrm{Na}$ Bahia, também foram observadas populações de $H$. seubertiana no município de Curaçá apresentando flores lilás. Horn (1985) cita uma grande variação no grau de esterilização dos estames menores. Na Bahia, foi observado que diferentes populações (p. ex. D.J.L. Sousa et al. 308, em Ubaitaba) com indivíduos possuindo inflorescências menores e com número reduzido de flores. Nessas populações, os estames menores não apresentavam formação de anteras ou de nenhum tecido produtor de grãos de pólen. Tal característica torna-se ainda mais interessante quando se compara $H$. seubertiana com Hydrothrix gardneri. Ambas estão bem distribuídas na região do Semiárido brasileiro, são predominantemente submersas fixas, possuem flores amarelas e, dentre as Pontederiaceae, H. gardneri é a única espécie que apresenta um único estame, demonstrando uma forte relação entre as duas espécies. As flores de $H$. seubertiana iniciam a antese em torno de 9:00 horas da manhã e permanecem abertas até cerca de 15:00 horas.

\subsection{Heteranthera zosterifolia Mart., Nov. Gen. Sp. Pl.} 1: 7.1823.

Figuras 12A-H, 13.

Erva submersa, ereta, ca. $30 \mathrm{~cm}$ alt. Folhas submersas alternas, espiraladas, ao longo do caule, sésseis; limbo linear a estreito-oboval, 1,8-3 ×0,3-0,5 $\mathrm{cm}$, glabro, ápice obtuso, base atenuada; lígula membranácea, ca. $0,5 \mathrm{~cm}$ compr., hialina, ápice arredondado. Cimeiras 2-floras; pedúnculo ca. 0,7 cm compr.; bráctea largo-elíptica, cimbiforme, ca. $1,1 \mathrm{~cm}$ compr., ápice obtuso, mucronado, múcron ca. $0,2 \mathrm{~mm}$ compr.; raque ca. $1 \mathrm{~cm}$ compr., verde, glabra. Flores 


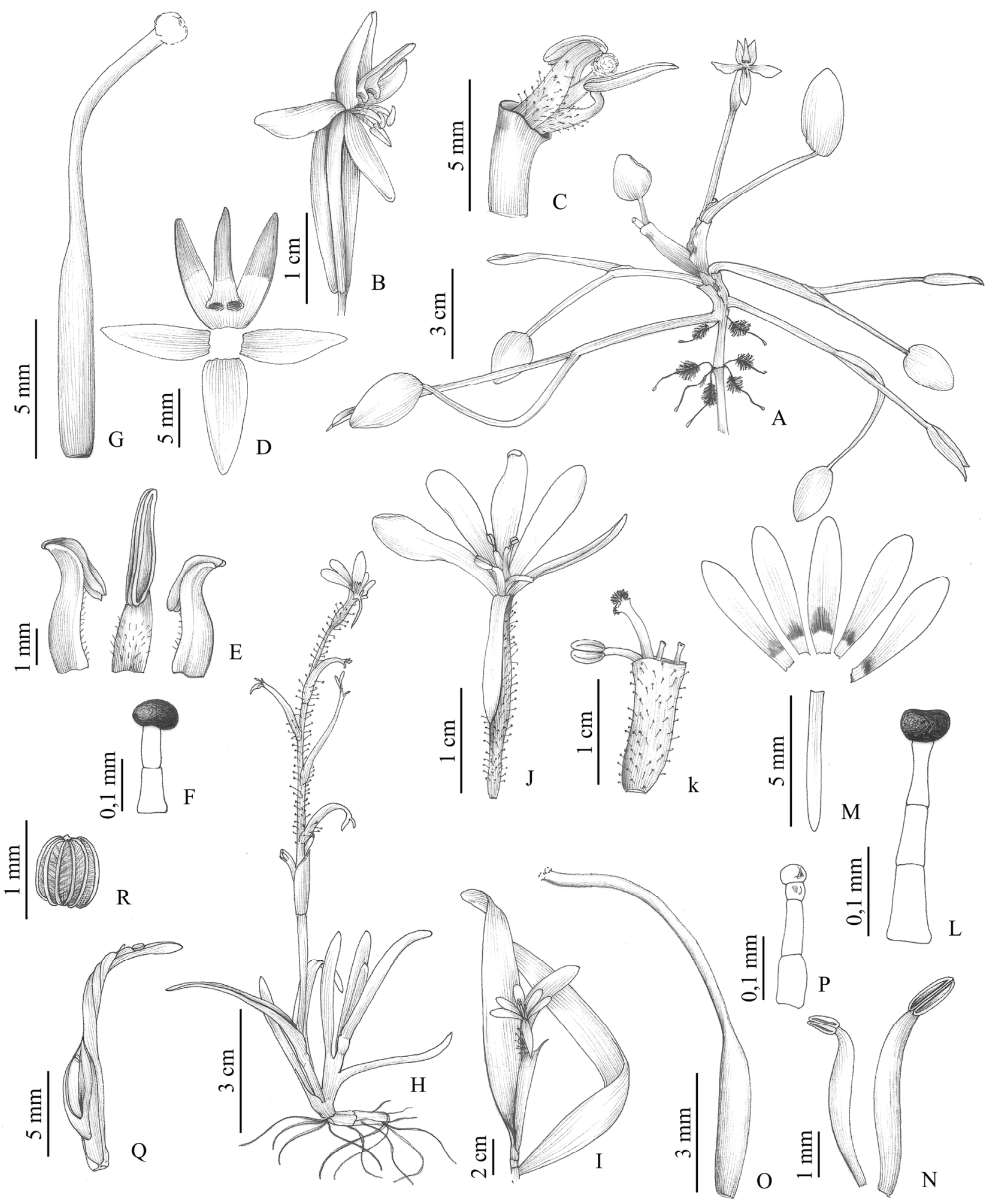

Figura 11. A-G. Heteranthera rotundifolia: A- hábito; B- inflorescência uniflora com a bráctea aberta; C- ápice do tubo do perigônio com os lobos retirados, dando ênfase na disposição dos estames e do gineceu; D- detalhe da disposição dos lobos (retirados do tubo do perigônio); E- androceu com o estame maior central e os estames menores laterais; F- tricoma dos filetes; G- gineceu. H-R. H. seubertiana: H- hábito de um indivíduo emergente; I- porção apical com detalhe no ramo florífero de um indivíduo submerso fixo; J- flor; K- flor com os lobos retirados, evidenciando a presença de um estame e dois estaminódios, formados basicamente pelos filetes dos estames menores; L- tricoma da face externa do tubo do perigônio e raque; M- detalhe da disposição dos lobos (retirados do tubo do perigônio); N- androceu com o estame maior e um dos estames menores; O- gineceu; P- tricoma dos estiletes; Q- fruto com o antocarpo fendido e torcido; R- semente. (A-G- Sousa 271; H- Cardoso 863; I- Sousa 308; J- Queiroz 9665; K- Sousa 308; L-R- Cardoso 963) 
com tubo do perigônio ca. 3,5 mm compr., verde, face externa glabra; lobos externos ca. $5 \mathrm{~mm}$ compr., 1 posterior elíptico, lilás, e 2 elípticos a lanceolados, lilás, lobos internos ca. $5 \mathrm{~mm}$ compr., 1 anterior elíptico a lanceolado, lilás, mácula ausente, e 2 anteriores elípticos $(5+1)$, lilás; estames 3 , pubérulos. Cápsulas e sementes não vistas.

Está restrita a América do Sul, principalmente na porção subtropical do continente (Schulz 1942; Castellanos 1958; Horn 1985, 1987). De acordo com Amaral (2014), a espécie ocorre no Sudeste e Sul do Brasil e na Bahia. D10, F4: no rio Crumaí, litoral norte do estado, e em alagados do rio São Francisco e áreas de Caatinga.

Material examinado - Bom Jesus da Lapa, estrada para Calderão, 13ㅇำ'S, 43ำ13'W, 17 abr. 1980, R.M. Harley et al 21442

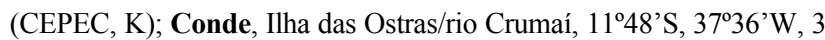
nov. 2001, D.L. Santana et al. 671 (ALCB); Mairi, São Bento das Lajes, 1913, P. Luetzelburg 1011 (K); Rio de Contas, 1913, P. Luetzelburg 13053 (K); Sobradinho, estrada para Morro do Serrote, 09'23'26”S, 4048'28”W, 5 jun. 2010, M.L. Guedes et al. 17202 (ALCB).

Heteranthera zosterifolia apresentam folhas ao longo do caule, lineares, sésseis, frequentemente submersas, e filetes inflados. Dentre as espécies brasileiras, tais caracteres são compartilhados com $H$. seubertiana. Entretanto, as espécies são distintas pela presença de inflorescências sempre bifloras, flores lilás e a face externa das flores glabras em $H$. zosterifolia, enquanto que em $H$. seubertiana, as inflorescências apresentam geralmente mais de duas flores amarelas e face externa pubérula.

3. Hydrothrix Hook. f., Ann. Bot. (Oxford) 1: 89. 1887.

Ervas submersas. Folhas verticiladas, ao longo do caule, sésseis; limbo acicular. Inflorescências 2-floras, simulando uma única flor (pseudanto); brácteas obovais, tubulosas, fechadas; raque ausente. Flores sésseis, amarelas; tubo do perigônio com face externa glabra; lobos externos com margem inteira, 1 mediano posterior largo-elíptico a oval e 2 laterais anteriores lineares, lobos internos com margem inteira, 1 mediano anterior linear e 2 laterais posteriores largo-elípticos a ovais $(3+3)$, amarelos, lobo mediano anterior sem mácula, face abaxial dos lobos glabra; estame 1, filete cilíndrico, amarelo, glabro, antera oblonga, basifixa, amarela; ovário verde, glabro, trilocular, todos os lóculos férteis, multiovulados, estilete amarelo, glabro, estigma capitado, branco. Cápsulas esverdeadas a pardacentas; antocarpo ausente. Sementes elipsoides, longitudinalmente costadas a raramente lisas.

Por muito tempo, amostras provenientes do rio Salgado (Ceará), coletadas por Gardner $\left(n^{\circ} 1863\right) \mathrm{em}$ 1838, foram denominadas "Plantae dubiae affinitatis". Estes materiais apresentavam morfologia peculiar e acabaram sendo descritos por Hooker, com auxílio do Prof. Asa Gray, em 1887, como um gênero novo, monoespecífico, de Pontderiaceae (Hooker 1887), Hydrothrix.

Hydrothrix incluí apenas uma espécie e é frequentemente referido como endêmico do Nordeste do Brasil (Hooker 1887; Amaral 2014). Durante este trabalho, foi possível examinar espécimes que ocorrem na porção semiárida do norte do estado de Minas Gerais. Assim, o gênero Hydrothrix parece ser endêmico da região Semiárida do Brasil.

3.1. Hydrothrix gardneri Hook.f., Ann. Bot. 1: 90. 1887.

Figuras 12I-P, 13 e 14I.

Erva submersa, $10-50 \mathrm{~cm}$ alt. Folhas submersas, verticiladas, ao longo do caule, sésseis; limbo acicular, 2-4 × ca. 0,05 cm, glabro; lígula membranácea, 0,3$0,4 \mathrm{~cm}$ compr., hialina a castanha, ápice eroso. Inflorescências 2-floras; pedúnculo ca. $1 \mathrm{~cm}$ compr.; bráctea tubulosa, ca. 0,6 $\mathrm{mm}$ compr., ápice bífido, retuso, glabra. Flores com tubo do perigônio 2-3 $\mathrm{mm}$ compr., esverdeado, face externa glabra; lobos externos ca. 2,5 mm compr., 1 posterior largo-elíptico a oval, amarelo, e 2 anteriores lineares, amarelos, lobos internos ca. $2 \mathrm{~mm}$ compr., 1 anterior linear, amarelo, mácula ausente, e 2 posteriores largo-elípticos a ovais $(3+3)$, amarelos; estame 1, glabro. Cápsulas 4-5 mm compr., esverdeadas a castanhas. Sementes elipsoides, 0,8-1 mm compr., castanho-claras, costadas a lisas.

A espécie é endêmica do Brasil, e citada apenas para a Região Nordeste (Hooker 1887; Amaral 2014), nos estados da Bahia, Pernambuco e Ceará (Amaral 2014). Sua área de distribuição, no entanto, abrange também a porção norte do estado de Minas Gerais. B8, D6, F4: poucas populações em pequenos corpos d'água na margem de estradas, no norte e sudoeste do Estado, principalmente na porção marginal do rio Curaçá.

Material examinado - Curaçá, Arapuá/rio Curaçá, 0947'08'S, 3954'08'W, 3 maio 2008, J.A. Siqueira-Filho et al. 1987 (HVASF); João Dourado, BA-052 em direção a Irecê,

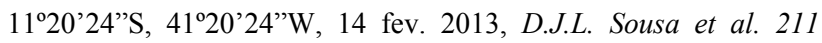

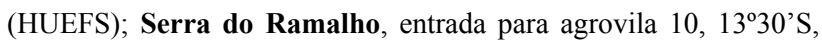

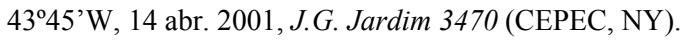

Material adicional examinado - BRASIL. ALAGOAS: Viçosa, Serra dos Irmãos, 28 nov. 2009, Chagas-Mota \& S. Brasileiro 6569 (MAC). PERNAMBUCO: Cabrobó, açude Mari, 28 jul. 2011, V.M. Cotarelli et al. 994 (HVASF). RIO GRANDE DO NORTE: Mossoró, 30 jun. 1982, C.N. Horn et al. 542 (IPA). MINAS GERAIS: Januária, Tejuco, 18 maio 2002, J.A. Lombardi et al. 4819 (BHCB).

Hydrothrix gardneri é de fácil reconhecimento, por ser uma erva submersa com folhas aciculares e verticiladas. A espécie é distinta dentre as monocotiledôneas principalmente pelas inflorescências com apenas duas flores opostas e simétricas, que se desenvolvem no ápice do pedúnculo, e são envolvidas por uma bráctea que se rompe no ápice. Cada flor apresenta os três lobos posteriores bem mais largos, maiores e amarelos e os três lobos anteriores lineares, 
inconspícuos e quase translúcidos, um estame e um pistilos. Os pseudantos desenvolvem-se na lâmina pistilo. O conjunto das duas flores da inflorescência d'água e suas flores apresentam sincronia na floração, simula uma única flor (pseudanto) com seis tépalas, iniciando a antese em torno das 7:00 horas da manhã e dois estames e um gineceu apocárpico com dois permanecendo abertas até cerca das 12:00 horas.

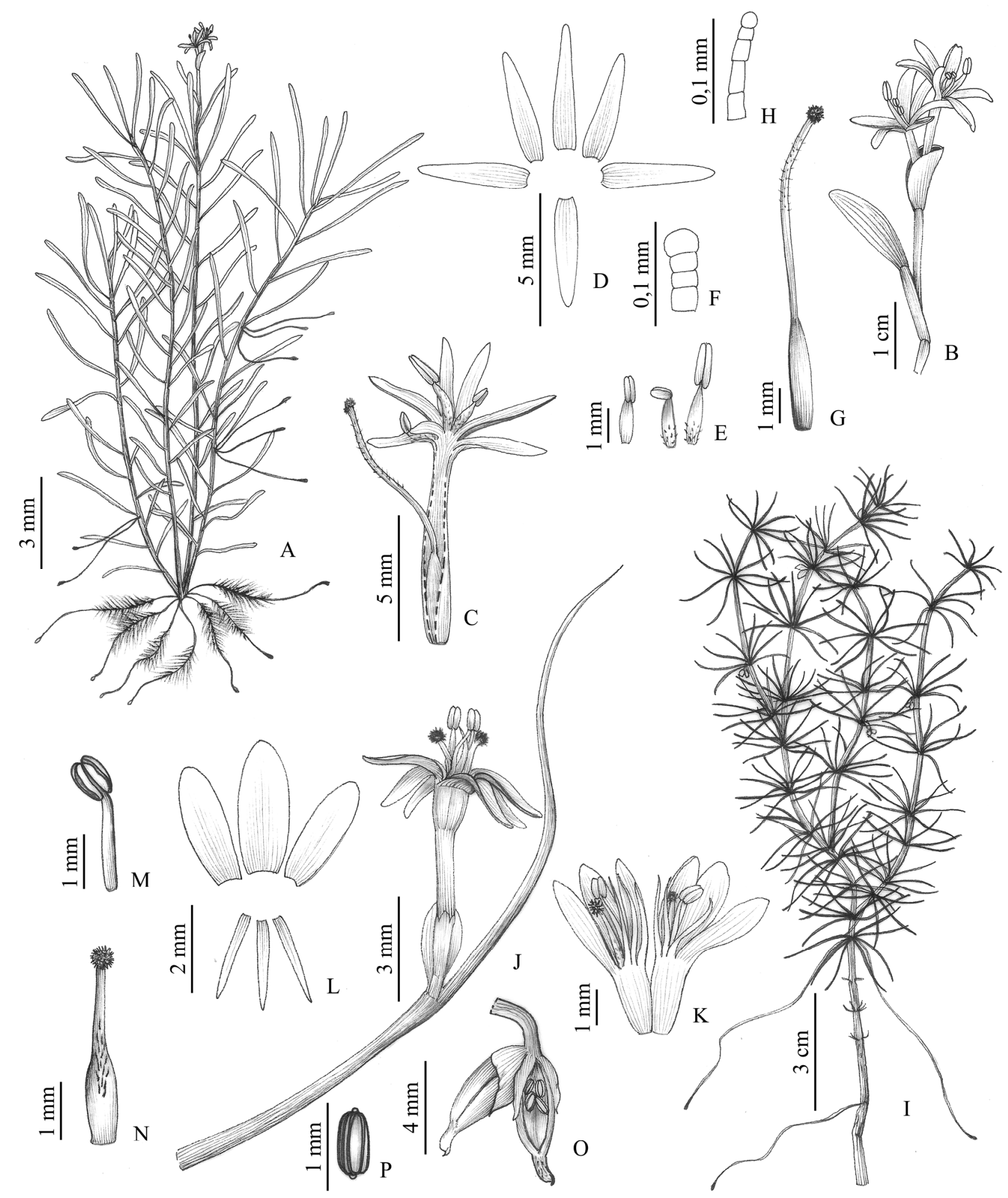

Figura 12. A-H. Heteranthera zosterifolia: A- hábito; B- detalhe de um ramo florífero; C- flor com corte longitudinal no tubo do perigônio; D- detalhe da disposição dos lobos (retirados do tubo do perigônio); D- androceu com um estame maior e dois menores; F- tricoma dos filetes; G- gineceu; H- tricoma dos estiletes; I-P. Hydrothrix gardneri: I- hábito; J- detalhe do ramo florífero; K- detalhe da inflorescência (pseudanto), sem a bráctea evidenciando as duas flores; L- detalhe da disposição dos lobos (retirados do tubo do perigônio); M- androceu, formado por um estame; N- gineceu; $\mathbf{O}$ - ramo frutífero com os dois frutos, fragmento do antocarpo inconspícuo na base de cada cápsula; P-semente. (A-H- Guedes 17202; I-P-Sousa 211) 


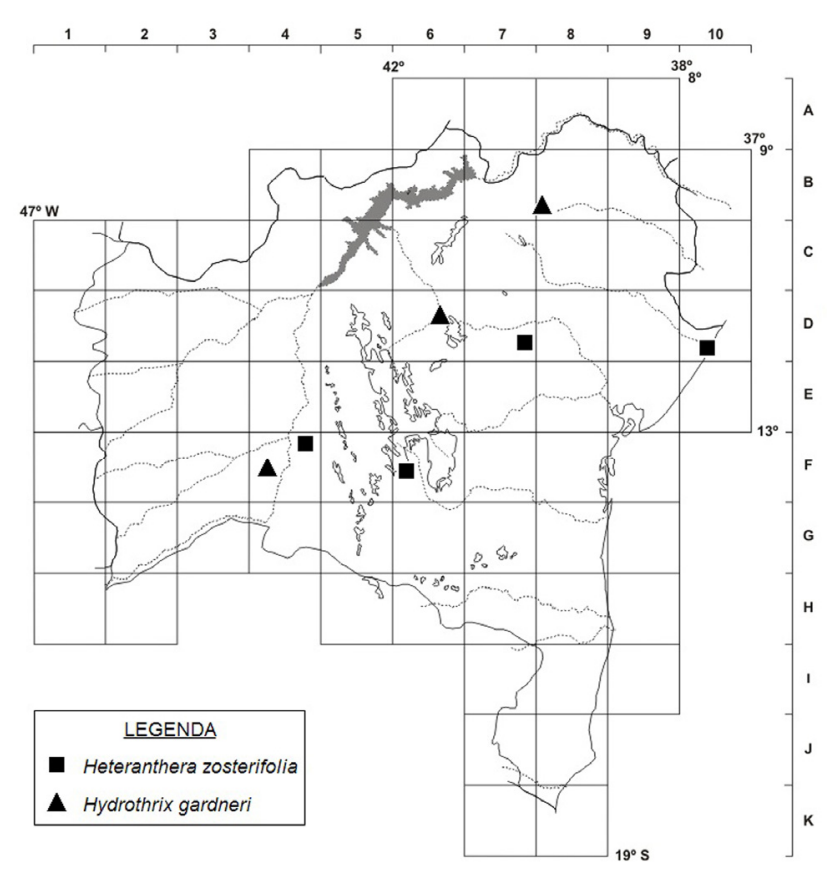

Figura 13. Distribuição de Heteranthera zosterifolia e Hydrothrix gardneri no estado da Bahia.

\section{Pontederia L., Sp. P1. 1: 288. 1753.}

Ervas emergentes ou flutuantes fixas. Folhas alternas, dísticas, basais ou ao longo do caule, pecioladas; pecíolos não inflados, cilíndricos; limbo elíptico a arredondado ou triangular; ápice agudo a arredondado; base atenuada a sagitada. Inflorescências cimeiras ou cimeiras formadas por unidades de cincinos, 8- a multifloras, 1-5 flores por unidade de cincino; brácteas obovais a lanceoladas, frequentemente cimbiformes, parcialmente fechadas; raque glabra, pubescente ou vilosa. Flores sésseis, lilás, azuis ou brancas, tubo do perigônio com face externa pubescente ou vilosa; lobos externos com margem inteira, 1 mediano posterior elíptico a estreito-elíptico e 2 laterais anteriores elípticos a ovais, lobos internos com margem inteira, 1 mediano anterior largo-elíptico a oval e 2 laterais posteriores ou anteriores largoelípticos $(3+3$ ou $5+1)$, lobo mediano anterior com mácula, face abaxial dos lobos acompanhando o indumento do tubo; estames 6, filetes cilíndricos, brancos ou lilás a azulados, pubescentes, anteras homomorfas, oblongas a sagitadas, basifixas, castanhos ou azuladas; ovário esverdeado ou lilás, glabro, trilocular, apenas um lóculo fértil, uniovulado, estilete lilás a esbranquiçado, glabro ou pubescente, estigma capitado a trilobado, branco. Aquênios esverdeados ou castanhos; antocarpo bem desenvolvido, verde, torcido no ápice, equinado ou alado. Sementes ovoides, lisas.

Pontederia está presente principalmente nas Américas, desde os Estados Unidos até a Argentina, porém apresenta registros recentes para o continente australiano (Lowden 1973; Crow 2003). Para o Brasil, Amaral (2014) cita cinco espécies, das quais três são referidas para a Bahia. Neste trabalho, são reconhecidas quatro espécies de Pontederia para o estado da Bahia.
O gênero é facilmente distinto dos demais da família por apresentar inflorescências vistosas e maiores que $10 \mathrm{~cm}$ de comprimento, exceto em $P$. subovata, que possui inflorescências que não ultrapassam $4 \mathrm{~cm}$. Além disso, em todas as espécies, dos três lóculos do gineceu, apenas um é fértil, com um único óvulo grande, que leva à formação de um fruto do tipo aquênio. Eram reconhecidas apenas quatro espécies de Pontederia, porém Lowden (1973) incluiu as duas espécies de Reussia Endl., R. subovata (Seub.) Solms e $R$. rotundifolia (L.f.) A.Cast no gênero. Pontederia inclui dois subgêneros: Pontederia subg. Pontederia, com plantas eretas e aquênios com antocarpo alado, e Pontederia subg. Reussia (Endl.) Lowden, com plantas decumbentes e aquênios com antocarpo equinado.

\section{Chave para as espécies}

1. Inflorescências 8-12-floras; flores com 5 lobos anteriores e 1 lobo posterior $(5+1)$.....P. subovata

1'. Inflorescências 30-multifloras; flores com 3 lobos anteriores e 3 lobos posteriores $(3+3)$.

2. Plantas decumbentes com folhas ao longo do caule;raque vilosa, aquênios com antocarpo equinado .......................... 4.2. P. rotundifolia

2'. Plantas eretas com folhas basais; raque glabra ou pilosa, aquênios com antocarpo alado.

3. Folhas cordiformes a largo-ovais, nunca sagitadas; raque da inflorescência pilosa; 2 ou 3 flores por unidade de cincino; estilete pubérulo ............................. 4.1.P. cordata

3'. Folhas sagitadas; raque da inflorescência glabra; 4 ou 5 flores por unidade de cincino; estilete glabro

4.3. P. sagittata

4.1. Pontederia cordata L., Sp. P1. 1: 288. 1753.

Figuras $15 \mathrm{~A}-\mathrm{K}, 16$ e $18 \mathrm{~A}-\mathrm{C}$.

Erva emergente, ereta, ca. $50 \mathrm{~cm}$ alt. Folhas submersas não vistas. Folhas emersas alternas, dísticas, basais; pecíolo nunca inflado, 13-30 × 0,3$0,5 \mathrm{~cm}$, verde, glabro; limbo cordiforme a largo-oval, 10-22 × 3,5-11 cm, glabro; lígula fibrosa, ca. $4 \mathrm{~cm}$ compr., vinácea, ápice obtuso. Cimeiras ca. 160floras, formadas por cincinos 2- ou 3-floros; pedúnculo 7-10 cm compr.; bráctea oboval, 3,5-5,5 $\mathrm{mm}$ compr., ápice arredondado, levemente retuso, mucronado, múcron 0,9-1 mm compr.; raque 7,5-11 cm compr., verde, pilosa. Flores com tubo do perigônio 2-3 $\mathrm{mm}$ compr., branco com base esverdeada ou lilás com base esverdeada, face externa pilosa; lobos externos 5-7 $\mathrm{mm}$ compr., 1 posterior e 2 anteriores elípticos, brancos, lilás ou azulados, lobos internos 5-7 mm compr., 1 anterior largo-elíptico a oval, com mácula amarela basal e 2 posteriores elípticos $(3+3)$, brancos, lilás ou azulados; estames 6, pubérulos na porção apical. Aquênios ca. $5 \mathrm{~mm}$ compr., castanhos; antocarpo enegrecido, 6-alado, alas com margem denteada, não equinado. Sementes não vistas. 


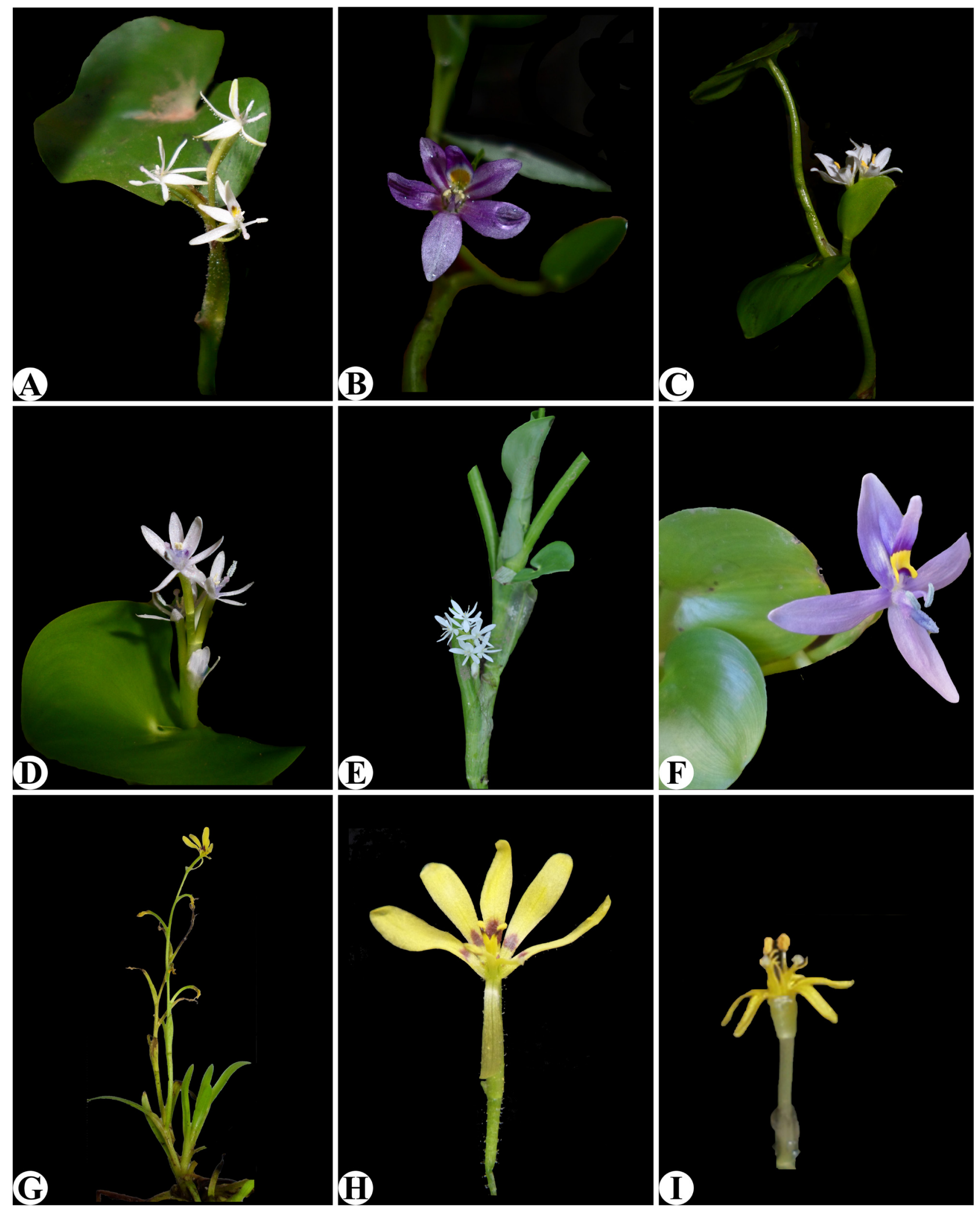

Figura 14. A. Heteranthera multiflora. B, C. H. oblongifolia. D. H. peduncularis. E. H. reniformis. F. H. rotundifolia. G, H. H. seubertiana. I. Hydrothrix gardneri.

Ocorre nas Américas, desde o Canadá até a Argentina (Schulz 1942; Castellanos 1958; Lowden 1973; Novelo \& Ramos 1998). D2, E2: restrita ao oeste do estado.

Material selecionado - Barreiras, Rio de Janeiro, $12^{\circ} 04^{\prime} \mathrm{S}$,
4536'W, 2 nov. 1987, L.P. Queiroz 2104 (CEPEC, HRCB, HUEFS, NY); Formosa do Rio Preto, Arroz/Rio Preto,

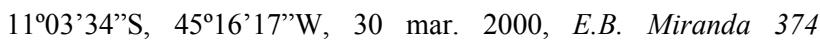
(HUEFS); Luiz Eduardo Magalhães, $12^{\circ} 18^{\prime} 28^{\prime \prime}$, 454'06”'W, 21 set. 2003, A.B. Xavier et al. 59 (ALCB). 
Dentre as espécies da Bahia, apenas Pontederia cordata e $P$. sagittata são plantas emergentes e eretas. Além das duas espécies, Pontederia parviflora Alexander, também apresenta-se emergente; mas no Brasil, é registrada apenas para o Pantanal (Pott \& Pott 2000). Pontederia cordata, no entanto, possui inflorescências mais longas e com poucas flores abertas por dia, além dos tricomas, que em $P$. parviflora são mais longos e sem uma célula glandular.

Segundo Lowden (1973), P. cordata inclui três variedades: $P$. cordata var. cordata, com folhas cordiformes; $P$. cordata var. ovalis (Mart.) Solms, com folhas ovais e raque da inflorescência com tricomas; e $P$. cordata var. lancifolia (Muhl.) Torr., com folhas lanceoladas (Sul e Sudeste). Amaral (2014) reconhece apenas $P$. cordata var. cordata (Centro-Oeste, Sudeste e Sul) e P. cordata var. ovalis (todas as Regiões, exceto na Região Norte). A análise dos espécimes da Bahia mostrou uma grande variação no formato do limbo das folhas, que apesar de ser na maioria dos materiais de cordiforme a largo-oval, também pode ser de lanceolado (p. ex. Araújo 329) a oval (p. ex. Amorim 562), ainda que a raque das inflorescências seja sempre indumentada. Variações também foram observadas em cultivo. Indivíduos que apresentavam folhas mais largas no campo passaram a produzir folhas mais estreitas em cultivo. Grandes variações na forma das folhas são referidas para outros grupos de plantas aquáticas, e parecem estar relacionadas a características ambientais (Sculthorpe 1967). Tendo em vista a variação observada nas folhas e os espécimestipo das três variedades não terem sido examinados, preferimos considerar a identificação dos espécimes da Bahia apenas no nível de espécie.

Pontederia cordata também apresenta variação na coloração das flores, desde brancas a lilás. Nas populações da Bahia, foram observados indivíduos com flores brevistilas, medistilas e longistilas, que iniciam a antese em torno das 8:00 horas da manhã, e permanecem abertas até aproximadamente às 14:00 horas.

4.2. Pontederia rotundifolia L.f., Suppl. P1. 192. 1781. Figuras 15L-S, 16 e 18D-E.

Erva flutuante fixa, decumbente, $30-140 \mathrm{~cm}$ alt. Folhas submersas não vistas. Folhas emersas alternas, dísticas, ao longo do caule; pecíolo nunca inflado, 24-50 × 0,8-1,3 cm, verde, glabro; limbo oval a triangular, 12-15 $\times 8-10 \mathrm{~cm}$, glabro, ápice obtuso, base cordada, raramente truncada, lobos ca. $2 \mathrm{~cm}$ compr., não imbricados; lígula fibrosa, ca. $11 \mathrm{~cm}$ compr., pardacenta, ápice arredondado, mucronado, múcron ca. $1 \mathrm{~mm}$ compr. Cimeiras ca. 72-floras, formada por unidades de cincinos, 2- ou 3-floros, às vezes reduzidos a 1 flor; pedúnculo 9-16,5 cm compr.; bráctea oval, 4-4,5 cm compr., ápice obtuso a arredondado, retuso, mucronado, múcron $0,5-1 \mathrm{~mm}$ compr.; raque $6,5-8 \mathrm{~cm}$ compr., verde, vilosa. Flores com tubo do perigônio 5-7 mm compr., branco com base esverdeada, face externa pilosa; lobos externos 4
$6 \mathrm{~mm}$ compr., 1 posterior e 2 anteriores elípticos, lilás, lobos internos 4-6 mm compr., 1 anterior largo-elíptico a oval, com mácula amarela basal, e 2 laterais posteriores elípticos $(3+3)$, lilás; estames 6 , pubérulos. Aquênios 11-16 mm compr., verdes; antocarpo verde, não alado, equinado. Sementes ovoides, ca. $4 \mathrm{~mm}$ compr., brancas a castanhas.

Ocorre nas Américas, tendo registros desde o México até a Argentina (Schulz 1942; Castellanos 1958; Lowden 1973; Novelo \& Ramos 1998; Crow 2003). No Brasil, Amaral (2014) refere a espécie para as Regiões Centro-Oeste, Norte e Nordeste, onde é citada para os estados da Paraíba e Piauí. Durante o desenvolvimento deste trabalho pequenas populações da espécie foram registradas pela primeira vez no estado. G8: nas margens, a jusante do Rio de Contas, no domínio da Mata Atlântica.

Material examinado - Itacaré, Rio de Contas, 14¹6'39”'S, 3859'48”'W, 8 mar. 2013, D.J.L. Sousa et al. 339 (HUEFS).

Material adicional examinado - BRASIL. PERNAMBUCO: Cabo de Santo Agostinho, 11 dez. 1968, D. Andrade-Lima 685932 (IPA); Moreno, Reserva Ecológica de Gurjaú, 25 nov. 2004, J.A. Siqueira-Filho 1440 (HVASF).

Pontederia rotundifolia está incluída em Pontederia subg. Reussia, cuja principal característica é a presença de acúleos no antocarpo. Através de observações em microscopia de luz foi possível verificar que os acúleos são formados a partir de proeminências epidérmicas presentes na base dos tricomas, que são compridos, multicelulares e hialinos, dispostos principalmente na base do tubo do perigônio e que caem com a formação dos acúleos. A espécie é de fácil identificação por se tratar de ervas decumbentes, com caules radicantes, e folhas com o limbo com base cordada, raramente truncada. As flores iniciam a antese em torno das 8:00 horas da manhã e permanecem abertas até cerca das 13:00 horas.

\subsection{Pontederia sagittata C.Presl, Reliq. Haenk. 1(2):} 116. 1827.

Figuras 16, 17A-H e 18F-H.

Erva emergente, ereta, $50-190 \mathrm{~cm}$ alt. Folhas submersas não vistas. Folhas emersas alternas, dísticas, basais; pecíolo nunca inflado, 17-130 × 0,9$2,5 \mathrm{~cm}$, verde, glabro; limbo largo-elíptico a oval, 27$35 \times 19-22 \mathrm{~cm}$, glabro, ápice obtuso a agudo, base sagitada, lobos 9-11 cm compr., não imbricados; lígula fibrosa a membranácea, $3-10,5 \mathrm{~cm}$ compr., esverdeada a pardacenta, ápice truncado. Cimeiras ca. 360-floras, formada por cincinos 4- ou 5-floros; pedúnculo 10-15 cm compr.; bráctea lanceolada, ca. $5 \mathrm{~cm}$ compr., ápice agudo, aristado; raque 11,5-14 cm compr., verde, glabra. Flores com tubo do perigônio 6-7 mm compr., branco com base esverdeada, face externa pubérula; lobos externos ca. $4 \mathrm{~mm}$ compr., 1 posterior e 2 anteriores elípticos, azulados, lobos internos ca. $5 \mathrm{~mm}$ compr., 1 anterior largo-oval, com mácula amarela basal, e 2 laterais posteriores, elípticos $(3+3)$, azulados; estames 6, 3 maiores pubérulos. Aquênios 7-8 mm compr., verdes; antocarpo verde, 6-alado, alas 


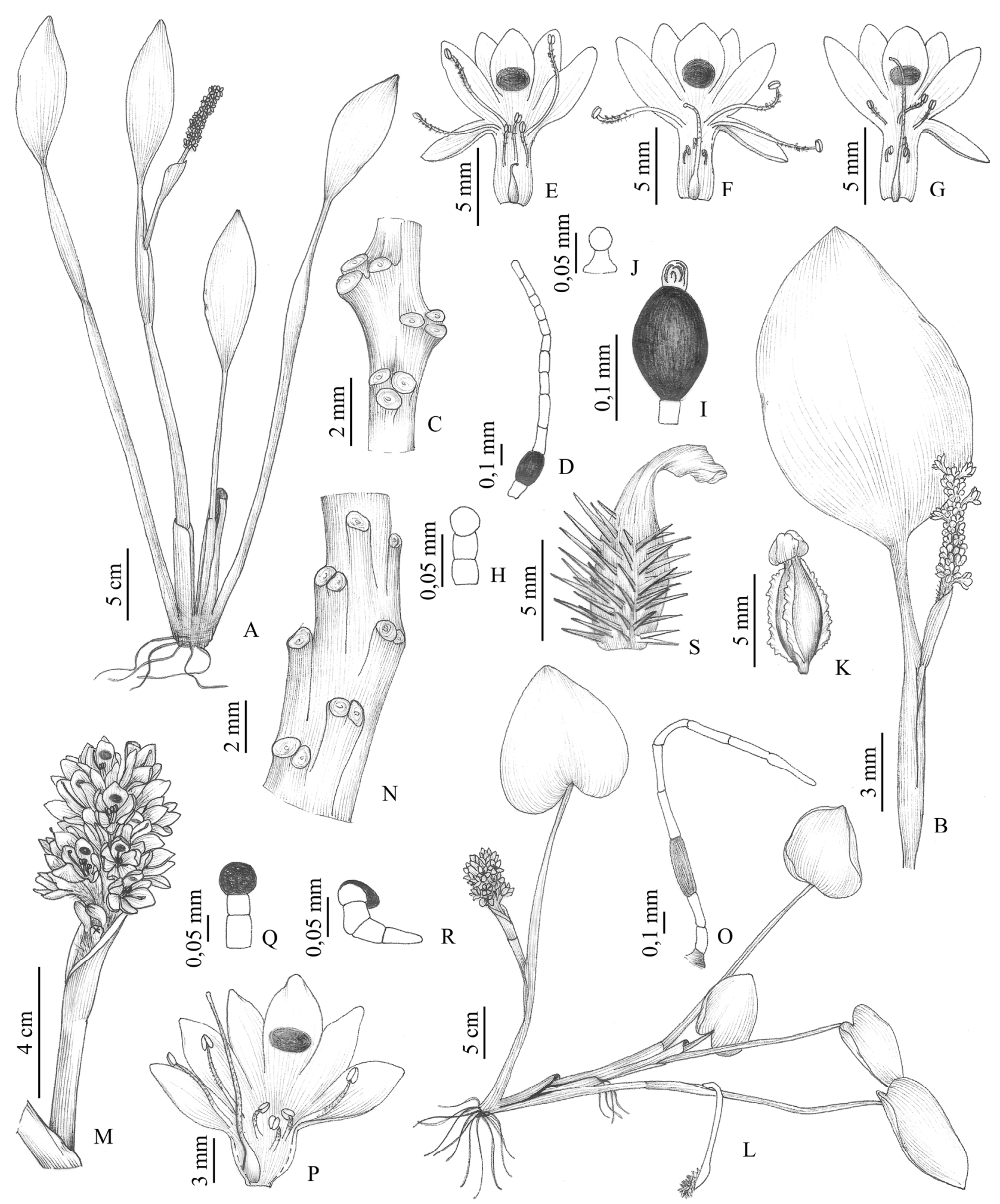

Figura 15. A-K. Pontederia cordata: A- hábito; B- detalhe do ramo florífero; C- detalhe da raque com as flores e tricomas retirados evidenciando a cicatriz das flores nas unidades de cincinos; D- tricoma da face externa do tubo do perigônio e raque; E- flor brevistila com corte longitudinal; F- flor medistila com corte longitudinal; G- flor longistila com corte longitudinal; $\mathbf{H}-1^{\circ}$ tipo de tricoma dos filetes; I- $2^{\circ}$ tipo de tricoma dos filetes; J- tricoma dos estiletes; K- fruto com antocarpo alado, alas com margem denteada. L-S. P. rotundifolia: L- hábito; M- inflorescência; $\mathbf{N}$ - detalhe da raque com as flores e tricomas retirados evidenciando a cicatriz das flores nas unidades de cincinos, às vezes reduzidas a uma única flor; $\mathbf{O}$ - tricoma da face externa do tubo do perigônio, com projeção epidérmica na base; P- flor longistila com corte longitudinal; Q- tricoma dos filetes; R- tricoma dos estiletes; S- fruto com antocarpo equinado. (A-B- Queiroz 2104; L-S- Sousa 339)

com margem lisa a irregular, não equinado. Sementes ovoides, ca. $4 \mathrm{~mm}$ compr., castanhos.
Ocorre na América Central, onde possui muitos registros, e na América do Sul, onde é citada apenas 
para o Brasil (Castellanos 1958; Lowden 1973; Crow 2003). Amaral (2014) cita a espécie para a Região Sudeste e na Bahia. G8: apenas no rio Almada, município de Itajuípe, na Mata Atlântica do sul do estado.

Material selecionado - Itajuípe, União Queimada, 14 maio 1987, T.S. Santos 4305 (CEPEC, HUEFS).

Dentre as Pontederiaceae, Pontederia sagittata se destaca pelo porte alto, chegando a quase $2 \mathrm{~m}$ de altura, com as maiores folhas referidas para a família, com o limbo atingindo cerca de $30 \mathrm{~cm}$ de comprimento, sendo também sagitado. As inflorescências apresentam um grande número de flores abertas por dia, de coloração lilás a azulada e com face externa do tubo do perigônio e porção central das tépalas pubérulas. É também a única espécie no gênero com estilete glabro. Lowden (1973) menciona a presença de flores tristilas para a espécie. Nas poucas populações de $P$. sagittata encontradas na Bahia, no entanto, foram observadas apenas flores medistilas, que iniciam a antese em torno de 9:00 horas da manhã e permanecem abertas até cerca das 15:00 horas.

4.4. Pontederia subovata (Seub.) Lowden, Rhodora 75: 478. 1973.

Figuras 16, 17 I-P, 18I.

Erva emergente, decumbente, raramente ereta, ca. $20 \mathrm{~cm}$ alt. Folhas submersas não vistas. Folhas emersas alternas, dísticas, ao longo do caule; pecíolo nunca inflado, 9-12,3 × ca. 0,9 cm, glabro; limbo oboval a arredondado, 4-5 × 4,3-5,2 cm, glabro, ápice obtuso a arredondado, base arredondada a atenuada; lígula membranácea, ca. $7 \mathrm{~cm}$ compr., hialina, levemente esverdeada, ápice truncado. Cimeiras 8-12floras, 1 por unidade; pedúnculo 8,5-12,5 cm compr.; bráctea oboval, 2,5-3 cm compr., ápice obtuso, levemente retuso; raque 2,5-4 cm compr., verde, vilosa. Flores com tubo do perigônio 7-8 mm compr., lilás a azulado com base esbranquiçada, face externa vilosa; lobos externos 9-12 mm compr., 1 posterior estreito-elíptico e 2 anteriores elípticos, azulados, lobos internos 9-12 mm compr., 1 anterior largo-elíptico, com mácula amarela basal e 2 anteriores elípticos $(5+$ 1), azulados; estames 6, pubérulos na porção apical. Aquênios 8-12 mm compr., verdes a castanhos, antocarpo enegrecido, não alado, equinado. Sementes ovoides, ca. $3 \mathrm{~mm}$ compr., brancas a castanhas, lisas.

A espécie é referida apenas para a América do Sul, com ocorrência na Venezuela, Bolívia, Paraguai e Brasil (Castellanos 1958; Horn 1987; Pott \& Pott 2000; Hokche et al. 2008). Para o Brasil, Amaral (2014) cita a espécie apenas para o estado de São Paulo. G4: durante o desenvolvimento desse trabalho, foram observadas populações de $P$. subovata em alagados nos baixos do rio São Francisco, no domínio da Caatinga, região sudoeste da Bahia.

Material selecionado - Jacobina, 1837, J.S. Blanchet 2720 (K); Malhada, Lagoa Mocambo, 14²1'37''S, 4344'40''W, 23 jun. 2013, D.J.L. Sousa et al. 329 (HUEFS).

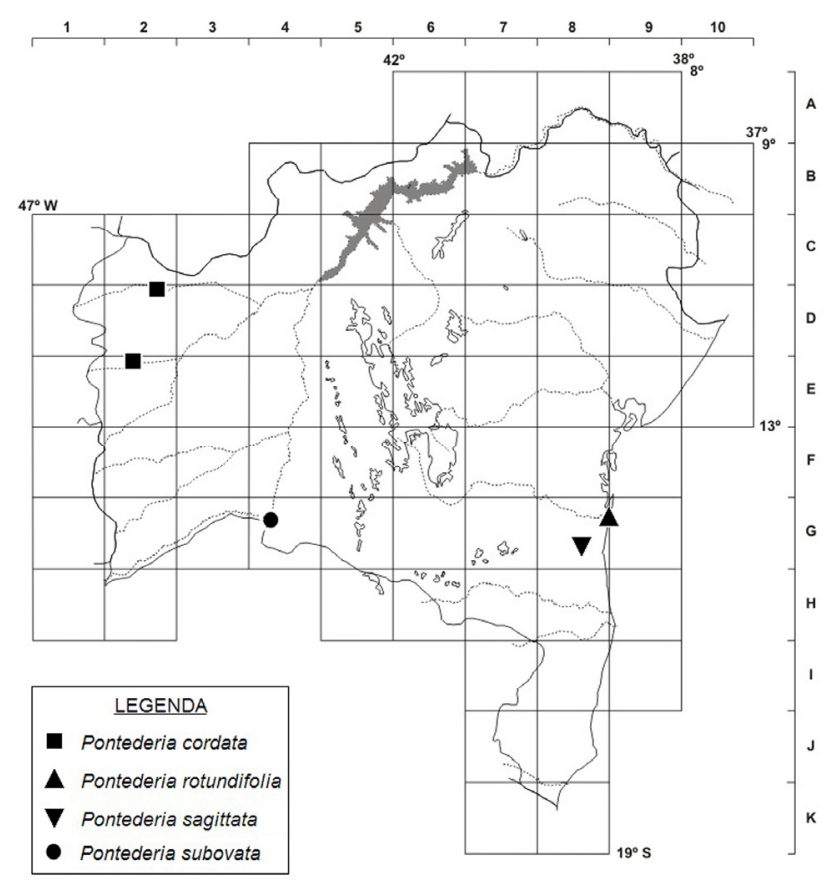

Figura 16. Distribuição de Pontederia cordata, P. rotundifolia, P. sagittata e P. subovata no estado da Bahia.

Material adicional examinado - BRASIL. MATO GROSSO: Barra do Garças, 1451'55'S, 52¹7'24'S, 10 jun. 1966, D.R. Hunt \& J.F. Ramos 5919 (NY). PIAUÍ: Campo Maior, açude Urum, 27 ago. 2004, F.O. Pires et al. 88 (EAC). RIO GRANDE DO SUL: Barra do Ribeiro, Rioce III, 26 abr. 2002, R.A.G. Viani et al. s.n (ESA 94670).

Pontederia subovata e $P$. rotundifolia formam o grupo de espécies decumbentes e com antocarpo equinado, sendo por essas características incluídas em Pontederia subg. Reussia. Em P. subovata, as folhas são obovais, podendo chegar a arredondadas, porém, mais raramente, podem ser encontrados indivíduos com folhas elípticas, se aproximando da forma das folhas descritas para $P$. triflora (Seub.) G.Agostini, D.Velázquez \& J.Velásquez, espécie considerada por Lowden (1973) como sinônimo de P. subovata. Amaral (2014) refere $P$. triflora para a Bahia, porém o único voucher citado pela autora é do Mato Grosso (Hunt 5919). Nenhum material coletado ou analisado da Bahia foi identificado como P. triflora.

Pontederia subovata é facilmente identificada pela raque da inflorescência e face externa do tubo do perigônio vilosas, apresentando os tricomas mais compridos dentre as espécies do gênero (Figura 17L). A espécie era conhecida por uma única coleta na Bahia, datada de 1837 (J.S. Blanchet 2720). Foi recoletada no estado mais recentemente (Jardim et al. 3400), porém havia sido incorretamente identificada como Eichhornia azurea. Com base nos espécimes examinados, foram encontrados indivíduos com flores brevistilas ou flores longistilas, que iniciam a antese cerca de 08:00 da manhã e permanecem abertas até cerca das 15:00. 


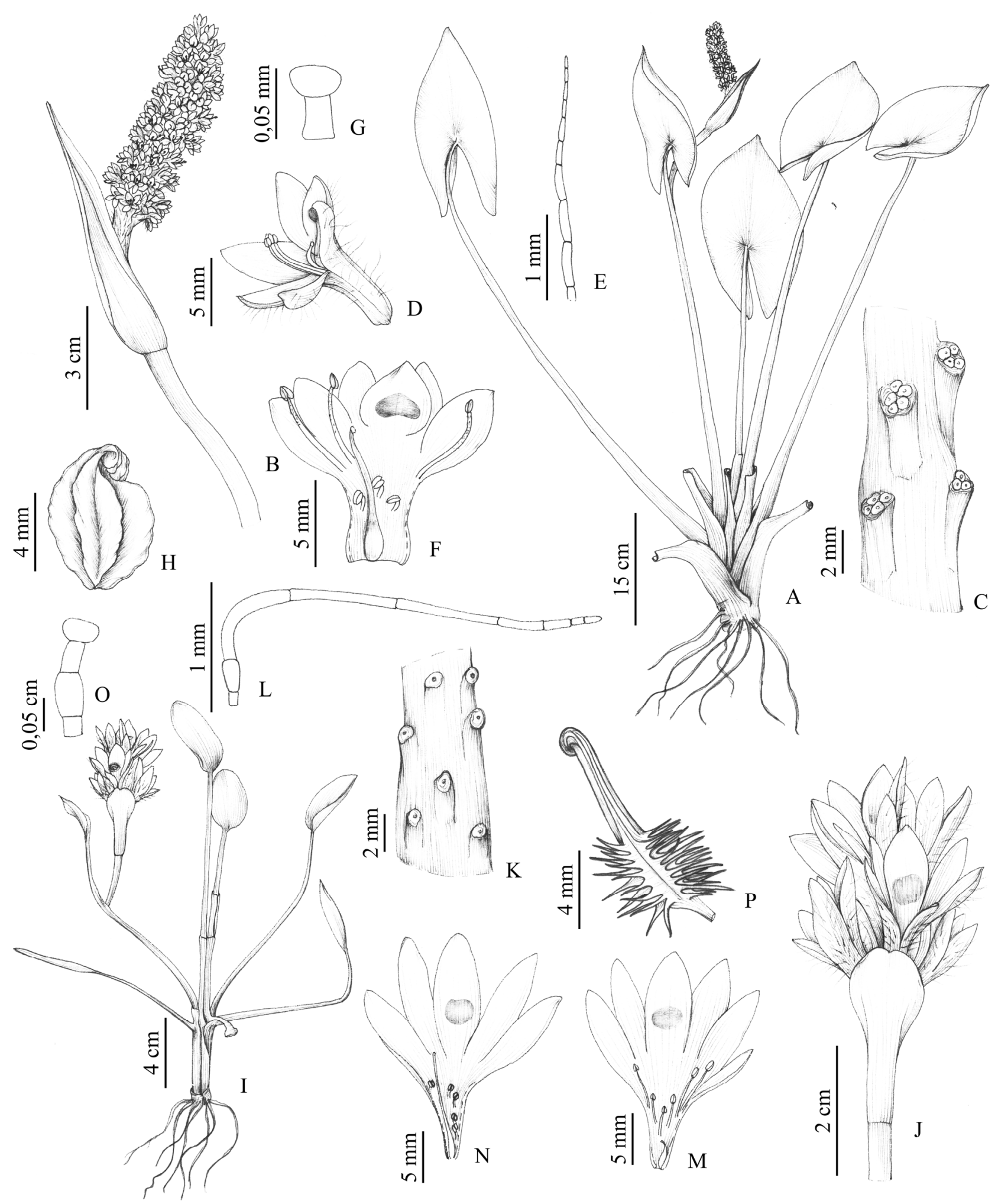

Figura 17. A-H. Pontederia sagittata: A- hábito; B- inflorescência; C- detalhe da raque com as flores retiradas evidenciando a cicatriz das flores nas unidades de cincinos; D- flor; E- tricoma da face externa do tubo do perigônio; F- flor medistila com corte longitudinal; G- tricoma dos filetes. H- fruto com antocarpo alado, alas com margem lisa a irregulares. I-P. P. subovata: I- hábito; J- inflorescência; K- detalhe da raque com as flores e tricomas retirados evidenciando a cicatriz das flores nas unidades florais, constituídas por uma flor; L- tricoma da face externa do tubo do perigônio e raque; M- flor brevistila; N- flor longistila; O- tricoma dos filetes; P- fruto com antocarpo equinado. (A-HSousa 311; I-P-Sousa 329) 


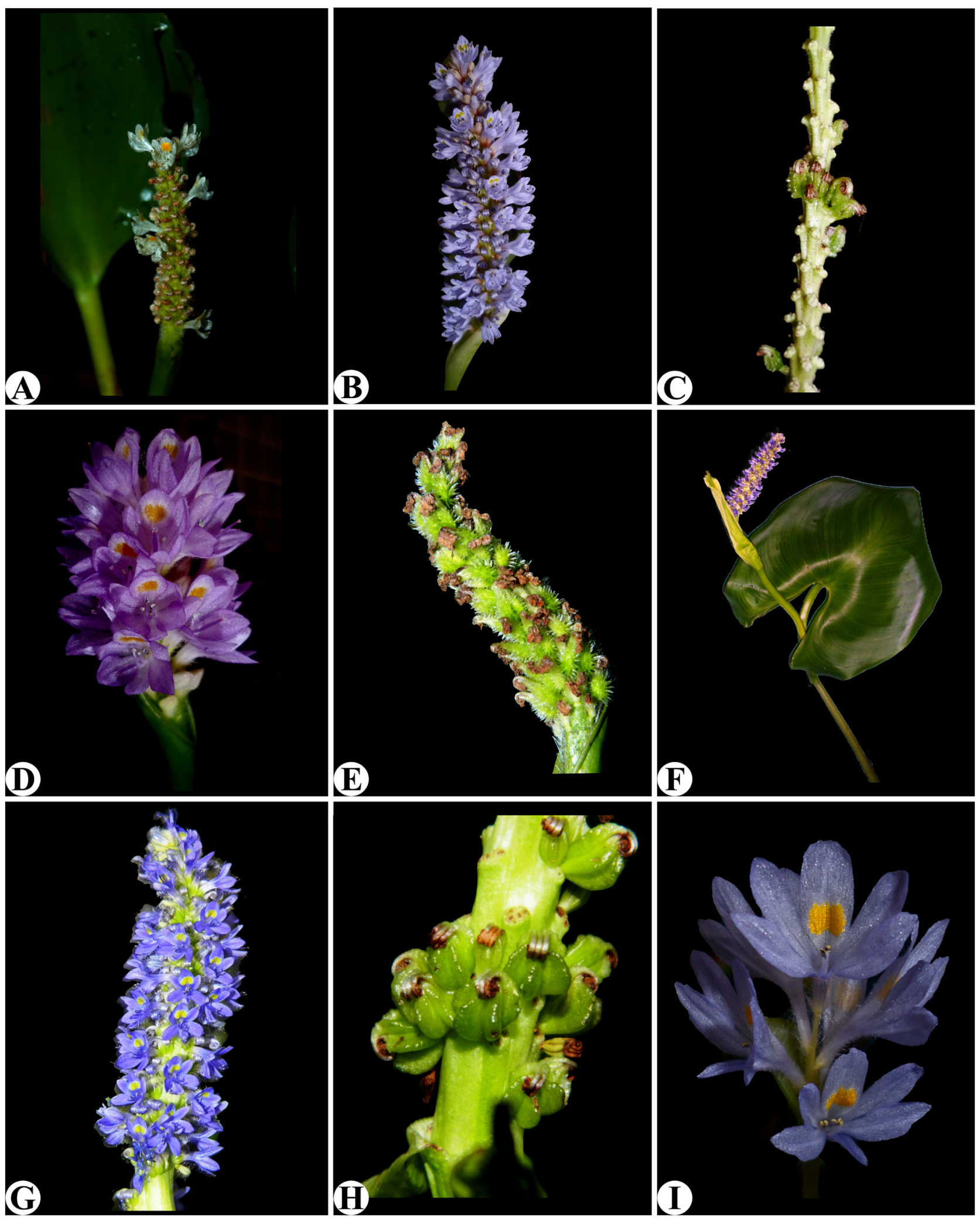

Figura 18. A-C. Pontederia cordata; D, E. P. rotundifolia; F-H. P. sagittata. I. P. subovata.

\section{AgRADECIMENTOS}

Agradecemos ao $\mathrm{CNPq}$, pela bolsa de mestrado do primeiro autor, e aos projetos Flora da Bahia (FAPESB APR 162/2007; CNPq Proc. 562278/2010-9: PROTAX e 483909/2012: Auxílio Universal), e também ao Programa de Pesquisa em Biodiversidade (PPBIO) do Semiárido, pelos recursos utilizados, e ao $\mathrm{CNPq} /$ REFLORA pelo repatriamento de Pontederiaceae do RBGKew. À Carla Lima, pela cobertura a nanquim das pranchas. 


\section{REFERÊNCIAS}

Amaral, M.C.E. 2014. Pontederiaceae In: Lista de Espécies da Flora do Brasil. Jardim Botânico do Rio de Janeiro. Disponível em http://floradobrasil.jbrj.gov.br/2010/FB000173; acesso em 14 de jan. 2014

APG III 2009. An update of the Angiosperm Phylogenetic Group classification for the orders and families of flowering plants: APG III. Botanical Journal of the Linnean Society 161: 105121.

Castellanos, A. 1958. Las Pontederiaceae del Brasil. Arquivos do Jardim Botânico do Rio de Janeiro 16: 147-236.

Cook, C.D.K. 1998. Pontederiaceae. In: K. Kubitzki (ed.), The Families and Genera of Vascular Plants. IV. Flowering plants: monocotyledons. Alismatanae and Commelinanae (except Gramineae). Springer Verlag, Berlin, p. 395-403.

Cronquist, A. 1981. An Integrated System of Classification of Flowering Plants. Columbia University Press, New York.

Crow, G.E. 2003. Pontederiaceae. In: B.E. Hammel, M.H. Grayum, C. Herrera \& N. Zamora (eds), Manual de Plantas de Costa Rica, Vol. III: monocotiledóneas. Missouri Botanical Garden Press, Saint Louis \& Instituto Nacional de Biodiversidad, Santo Domingo de Heredia, p. 822-828.

Dahlgren, R. \& Clifford, H.T. 1982. The Monocotyledons: a comparative study. Academic Press, New York.

Dahlgren, R.; Clifford, H.T. \& Yeo, P. 1985. The Families of the Monocotyledons: structure, evolution, and taxonomy. SpringerVerlag, Berlin.

Gomes, V.S. 2000. Levantamento das Espécies de Pontederiaceae Kunth Nativas do Brasil. Dissertação de Mestrado. Universidade Federal de Pernambuco.

Graham, S.W. \& Barret, S.C.H. 1995. Phylogenetic Systematics of Pontederiales. In: P.J. Rudall, P.J. Cribb, D.F. Cutler \& C.J. Humphries (eds), Monocotyledons: systematics and evolution. Royal Botanic Gardens, Kew.

Graham, S.W.; Kohn, J.R.; Morton, B.R. \& Eckenwalder, J.E. 1998. Phylogenetic congruence and discordance among one morphological and three molecular data sets from Pontederiaceae. Systematic Biology 47: 545-567.

Graham, S.W.; Olmstead, R.G. \& Barrett, S.C.H. 2002. Rooting phylogenetic trees with distant outgroups: a case study from the commelinoid monocots. Molecular Biology and Evolution 19(10): 1769-1781.

Hokche, O.; Berry, P.E. \& Huber, O. 2008. Pontederiaceae. In: Nuevo Catálogo de la Flora Vascular de Venezuela. Fundación Instituto Botánico de Venezuela, Caracas.
Hooker, J.D. 1887. On Hydrothrix, a new genus of Pontederiaceae. Annals of Botany 1: 89-94.

Horn, C.N. 1985. A Systematic Revision of the Genus Heteranthera (sensu lato; Pontederiaceae). Ph.D. dissertation, University of Alabama.

Horn, C.N. 1987. Pontederiaceae. In: G.F. Bocquet \& M.R. Crosby, (eds), Flora del Paraguay. Conservatoire et Jardin Botaniques de la Ville de Genève \& Missouri Botanical Garden, Geneva \& Saint Louis, p. 1-28.

Hutchinson, J. 1959. The Families of Flowering Plants, Vol. 2: Monocotyledons. 2 ed. Oxford University Press, Oxford.

Kuo-fang, W. \& Horn, C.N. 2000. Pontederiaceae. In: Flora of China. Disponível em http://www.efloras.org/florataxon.aspx? flora_id=2\&taxon_id=10722; acesso em 14 de jan. 2014

Lowden, R.M. 1973. Revision of the genus Pontederia L. Rhodora. 75: 426-483.

Ness, R.W.; Graham, S.W. \& Barrett, S.C.H. 2011. Reconciling gene and genome duplication events: using multiple nuclear gene families to infer the phylogeny of the aquatic plant family Pontederiaceae. Molecular Biology and Evolution 28(11): 3009-3018.

Novelo, A. \& Ramos, L. 1998. Pontederiaceae. In: G.C. Rzedowski \& J. Rzedowski (eds), Flora del Bajío de Regiones Adyacentes. Vol. 63. Instituto de Ecología, A.C. \& la Comisión Nacional para el Conocimiento y Uso de la Biodiversidad, Michoacán \& México, p. 1-19.

Pott, V.J. \& Pott, A. 2000. Plantas Aquáticas do Pantanal. Embrapa, Brasília.

Saarela, J.M.; Prentis, P.J.; Rai, H.S. \& Graham, S.W. 2008. Phylogenetic relationships in the monocot order Commelinales, with a focus on Philydraceae. Botany 86: 719-731.

Schulz, A.G. 1942. Las Pontederiaceae de la Argentina. Darwiniana 6: 45-82.

Schwartz, O. 1930. Pontederiaceae. In: A. Engler \& K. Prantl, (eds.), Die Natürlichen Pflanzenfamilien. Vol. 15a. 2 ed. W. Engelmann, Leipzig, p. 181-188.

Sculthorpe, C.D. 1967. The Biology of Aquatic Vascular Plants. Edward Arnold Ltd., London.

Seubert, M. 1847. Pontederiaceae. In: C.F.P. Martius, A.W. Eichler \& I. Urban (eds), Flora Brasiliensis. Vol. 3. Frid. Fleischer, Leipizig, p. 85-96.

Simpson, M.G. \& Burton, D. 2006. Systematic floral anatomy of Pontederiaceae. Aliso 22: 499-519.

Takhtajan, A. 1980. Outline of the classification of flowering plants (Magnoliophyta). Botanical Review 46: 226-359.

Thorne, R.F. 1983. Proposed new realignments in the angiosperms. Nordic Journal of Botany 3: 85-117.

\section{LISTA DE EXSICATAS}

Almeida, M.N.F. 31 (1.5); Alves, M. 1163 (2.2); Alves, M.B.B. 12 (1.5); Amorim, A.M. 562 (4.1), 1012 (1.5), 1787 (1.1); Andrade-Lima, D. 68-5932 (4.2), 74-7955 (4.1), 78-8449 (2.5); Aona, L.Y.S. 1078 (2.4), 1187 (1.2), 1202 (1.5), 1488, 1494 (1.2), 1541,1551 (1.5), 1590 (2.4); Araújo, G. 329 (4.1); Arouck, J. 184 (1.5); Arouck-Ferreira, J.D.C. 242 (2.5); Ataide, M. 3a (2.2), 3b (2.5); Atkins, S. 4651 (1.1), PCD5171 (2.2); Bautista, H.P. 713 (1.5), PCD3462 (2.2); Batista, G.S. 336 (2.6); Belém, R.P. 1789 (1.2); Blanchet, J. S. 2740 (3.6); Britto, K.B. 11 (1.5); Cardoso, D. 75 (1.5), 863 (3.6); Carneiro-Torres, D.S. 372 (2.5); Carvalho, A.M. 3847 (2.5); Carvalho, P.D. 254 (2.2); Chagas-Mota 6569 (3.1); Costa, D.M. 702 (1.5); Cotarelli, V.M. 1524 (2.5), 994 (3.1); Equipe Ecologia s.n ALCB 701 (1.2); Euponino, A. 377 (1.2); Félix, L.P. s.n HST 5390 (2.5); Ferreira, J.D.C.A. 235 (2.1); Florêncio, C.S. 46 (1.2); Fonseca, M.R. s.n. ASE 24972 (2.5); França, F. 662 (1.4), 1214 (1.3), 1215, 1636 (1.5), 1645, 1646 (1.2), 1762, 1764, 1770, 1989, 2222 (1.5), 2462 (1.1), 3247 
(1.3), 3249 (1.4), 3251 (2.2), 3256 (1.6), 3886 (1.1); Giulietti, A.M. 1715 (2.5), 1717 (2.2), 1764 (2.5), 1768 (2.2), 1972,2476 (2.5), 2579 (1.5), 2581 (1.2), 5484 (2.5), PCD 2986 (1.1), PCD 3393 (1.5), PCD 5505 (2.5); Gomes, D.J. 29 (1.2), 38 (1.5); Gomes, F.S. 270a (2.2), 270b (2.5); Gonçalves, L.M.C. 199 (1.5); Grupo Pedra do Cavalo 104 (1.2), 268 (1.5), 868 (3.6); Guedes, M.L. 3154 (1.2), 7013 (2.5), 7014 (1.6), 7016 (2.5), 7361 (1.1), 7822,9405 (1.2), 11610 (1.3), 12420, 13988 (1.2), 17202 (2.7), PCD3006 (2.5); Hage, J.L. 1438 (2.1), 1717 (1.5); Harley, R.M. 16261 (1.2), 16342 (2.5), 17467 (1.4), 21401 (1.6), 21442 (2.7), 21719 (2.6), 34074 (2.2), 54075 (2.5), 53821 (4.1), PCD5495 (2.2); Hatschbach, G. 56967, 63131 (1.5), 65155, 65812 (2.5); Hind, D.J.N. H51407 (2.5); Horn, C.N. 526 (2.2), 527 (2.5), 528 (2.6), 529 (1.6), 530 (2.6), 542 (3.1); Hunt, D.R. 5919 (4.4); Jardim, J.G. 3119 (2.1), 3400 (4.4), 3470 (3.1); Leite, K.R. 195 (1.2), 296 (1.5), 346, 359 (1.2), 365 (1.5), 438 (1.4), 481 (1.2), 482, 485, 498, 509, 518 (1.5); Lewis, G.P. 6722 (2.5); Lobo, C.M.B. 78 (1.5); Lombardi, J.A. 4819 (3.1); Luetzelburg, P. 252 (1.4); 1011, 13053 (2.7); Machado, M. 114 (4.1); Magalhães, C.M. 50 (2.1), 179 (1.2); Martius, C.F.P. 2366 (2.2); Matias, L.Q. s.n EAC 32591 (1.1); Matos, V.R. 9 (1.2); Medereiros, E.C.N. 70 (1.1); Melo, E. 1697 (1.5), 1699 (1.2), 1761, 1766 (1.5), 1805 (1.2), 2073, 6513, 8923 (2.5); Mendes, E. s.n ALCB 27754 (1.2) Monteiro, V.M. 65 (1.5); Mori, S.A. 11644 (2.1); Noblick, L.R. 1882 (2.2), 2732, 3676 (1.5), 3713 (2.2), 3716, 4055 (2.5), 4059 (1.5); Normando, L.R.O. 426, 454, 458 (1.4); Nunes, T.S. 1033, 1043 (2.5); Oliveira, C.R.S. 12 (1.2); Oliveira, E.L.P.G. 750 (1.5); Oliveira, R.P. 511 (1.1); Oliveira-Filho, L.C. 178 (1.5); Paula-Souza, J. 5488 (1.5); Pece, G.A. 1, 8 (1.2); Pereira, C.M.S.S. 3 (1.2); Pereira-Silva, G. 8479 (2.2); Pinto, G.C.P. $22 / 83$ (2.5); Pires, F.O. 88 (4.4); Prata, A.P. 1999 (1.2), 2042 (1.4), 2537 (1.2); Proença, C. 1737 (4.1); Queiroz, L.P. 400,1517 (1.5), 2104 (4.1), 2562 (1.5), 5882 (2.2), 7879 (2.6), 9062 (2.5), 9665 (2.6); Querino, R.N. 85 (2.6); Ramos, T. 3b (2.5); Ribeiro, A.J. 300 (1.1); Ribeiro, T. 27 (1.1); Rocha, E.A. 988 (1.2), 1779 (2.1); Saar, E. 5 (1.5); Santana, D.L. 101 (1.2), 652 (1.1), 671 (3.7), 673 (1.2); Santos, J.S. 153 (4.2); Santos, M.M. 171 (1.5); Santos, T.S. 4305 (4.3); Sena, T.S.N. 7 (1.5); Silva, E.B.M. 374 (4.1); Silva, L.A.M. 302 (1.5); Silva, M.S. 10 (1.2); Silva, U.C.S. 196 (1.2); Siqueira-Filho, J.A. 1440 (4.2), 1987 (3.1); Smidt, E.C. 184 (1.5); Sodertrom, T.R. 2183 (2.1); Sousa, D.J.L. 19 (2.2), 99 (1.3), 192 (2.2), 193, 203 (1.5), 204 (2.4), 208 (1.5), 209 (2.5), 210 (2.2), 211 (3.1), 239 (1.1), 240 (2.5), 270 (2.2), 271, 287, 289, 295, 297 (2.5), 298 (1.6), 300 (2.5), 302 (1.5), 303 (1.2), 304 (2.2), 307 (1.2), 308 (2.6), 309,310 (2.1), 311 (4.3), 317 (2.2), 319 (1.6), 325 (2.1), 327 (2.3), 329 (4.4), 333, 334 (2.2), 335 (2.5), 339 (4.2); Sousa, M.P. 23 (1.2); Stannard, B. PCD 5297 (2.5); Tenreiro, I.G.P. 38 (2.5); Viani, R.A.G. s.n ESA 94670 (4.4); Yoshida-Mas, K. BHRG 142 (2.2). 


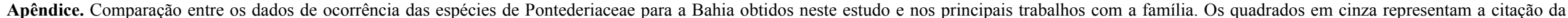

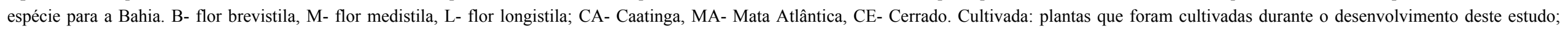
Horário: intervalo entre o horário de início da antese e fechamento das flores; * Nome adotado para espécie pelo autor.

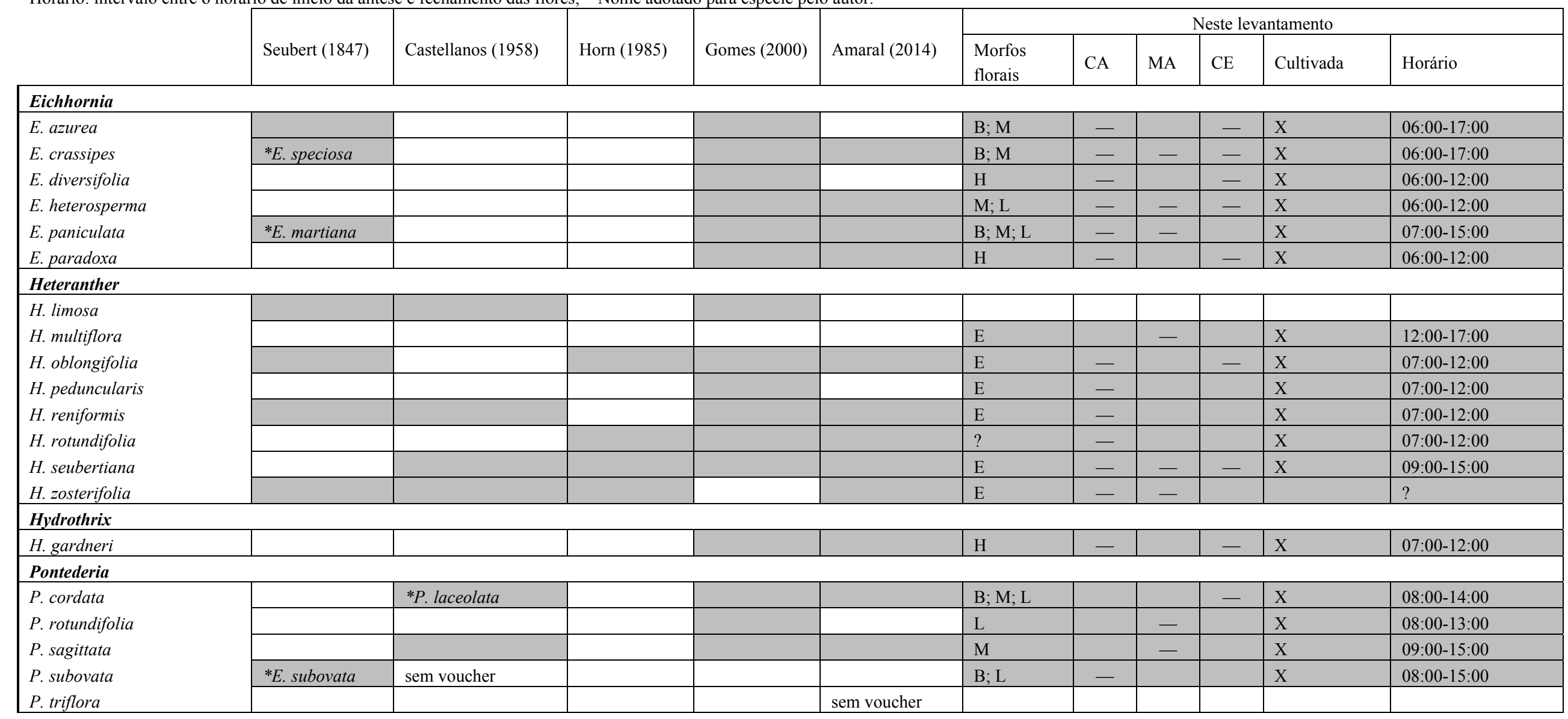

